\title{
Em torno da concepção de história de Sérgio Buarque de Holanda
}

[ Around the conception of the history of Sérgio Buarque de Holanda

Expresso meus agradecimentos a Telma Murari, supervisora técnica do Serviço de Arquivo Permanente do Sistema de Arquivos da Universidade Estadual de Campinas (Siarq), que guarda o Fundo Sérgio Buarque de Holanda, pela disponibilização do documento e autorização para sua publicação. Agradeço igualmente a Ana de Holanda, que, em nome dos demais herdeiros de Sérgio Buarque de Holanda, gentilmente consentiu na publicação do manuscrito. Ao professor Paulo Iumatti (IEB/ USP), agradeço, além dos incentivos, pela leitura e apontamentos sobre o material.

\section{Raphael Guilherme de Carvalhor}

CARVALHO. Raphael Guilherme de. Em torno da concepção de história de Sérgio Buarque de Holanda. Revista do Instituto de Estudos Brasileiros, Brasil, n. 70, p. 306-340, ago. 2018.

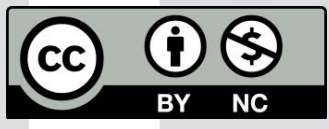

DOI: http://dx.doi.org/Io.II6o6/issn.23I6-90IX.voi7op306-340

I Universidade de São Paulo (USP, São Paulo, SP, Brasil). 
O documento original e inédito ora publicado pela Revista do Instituto de Estudos Brasileiros consiste em uma palestra pronunciada por Sérgio Buarque de Holanda (I902-I982) entre I967 e I969, a convite do Centro de Estudos Históricos Afonso Taunay (CEHAT), em que se reuniam e organizavam os estudantes de história da então Faculdade de Filosofia, Ciências e Letras (FFCL) da Universidade de São Paulo (USP). No catálogo do acervo pessoal do historiador, depositado desde I983 e aberto em I986 à consulta pública no Arquivo Central do Sistema de Arquivos da Universidade Estadual de Campinas (Siarq/Unicamp), encontra-se tão somente a seguinte informação sobre o manuscrito: "Palestra proferida por Sérgio Buarque de Holanda, discorrendo sobre o tema 'História', a convite dos alunos do 'Centro de Estudos Históricos Afonso de Taunay' [I96-]”.

Não é precisa, portanto, a sua data de pronunciação, que aparece catalogada como "I96-". No texto, a citação de um livro poderia tornar viável diminuir a imprecisão para situar a conferência pelo menos entre os últimos anos daquela década, porém, Generalization in historical science, citado como sendo de I966, é na verdade original de I963 - consta o exemplar, com grifos e notas de leitura, na Biblioteca Sérgio Buarque de Holanda, também alocada na Unicamp, Biblioteca Central, setor de Coleções Especiais e Obras Raras. Essa citação distraída, diferentemente do conjunto do texto estabelecido, passou em branco na revisão, realizada aliás intensamente, talvez mais de uma vez. Dificilmente, contudo, ele citaria um ano que ainda não existira. Algo bem mais concreto, no sentido de melhor situar temporalmente o documento, pode ser encontrado no rascunho da palestra, em oito páginas anexas, sob a mesma notação arquivística (cota) - mas que, esboço da alocução, não será por nós publicado agora, embora não por isso venha a perder o caráter legítimo de fonte manuscrita (HOLANDA, I96-). Nele, Buarque de Holanda revela, logo de início, que algumas noções que seriam na ocasião pronunciadas já se encontravam impressas em "um livro que publiquei há mais de trinta anos", ou seja, Raízes do Brasil, de outubro de I936: "Escrevi aquele livro em parte na Alemanha, terra clássica do historismo e do antipositivismo: o positivismo tal como era compreendido no século passado. E sem pensar retomava o fio dessas considerações naquela aula" (HOLANDA, I96-, anexo, p. I).

Com essa remissão a Raízes do Brasil, pode-se comprimir o arco temporal para situar a palestra, enfim, nos últimos três anos da década de I960, período, na 
universidade brasileira, e particularmente na USP, de intensa agitação política e de transformações institucionais, com a reforma universitária de I968, a movimentação estudantil e as aposentadorias compulsórias de professores, como, para lembrar apenas um dos principais nomes, Florestan Fernandes (I920-I995), regente até então da cátedra de Sociologia I na FFCL. Distante, portanto, de uma obsessão pela precisão de datas, esforço algo estéril, trata-se de tentar melhor situar o texto na trajetória do autor, nos contextos intelectual, institucional e político.

Buarque de Holanda, naquela segunda metade dos anos I960, continuava a dirigir a Coleção História Geral da Civilização Brasileira (CHGCB), iniciada em I959 na editora Difusão Europeia do Livro (Difel). Ele havia recentemente fundado o Instituto de Estudos Brasileiros (IEB), o qual dirigiu entre I962 e I964 e, depois, nos dois anos seguintes, foi o vice do diretor Egon Schaden (I9I3-I99I). Em I966, esteve nos Estados Unidos como professor visitante na Universidade de Indiana e na New York State University, além de ter cumprido tarefas acadêmicas em Yale e participar de eventos acadêmicos em Harvard e Colúmbia. As atividades em Stoney Brook (NY) se encerravam já em curso o ano de I967 e, antes de voltar ao Brasil, segundo sua cronologia de vida e obra ${ }^{2}$, Buarque de Holanda ainda se deslocou para a Europa, onde realizou pesquisas no Arquivo Histórico Ultramarino e na Biblioteca Nacional de Portugal, em Lisboa.

No mesmo ano de 1967, ele pronunciou conferência na Escola Superior de Guerra (ESG), cujo texto foi recentemente "descoberto", publicação inédita de 2008 e, desde então, importante para compreensão do posicionamento político e da autocrítica do historiador ao seu Raízes do Brasil, mas que também pode sugerir que ele, Buarque de Holanda, fora pouco incomodado pela ditadura e até mesmo que sua já gasta "teoria" do homem cordial era bem vista pelo órgão que elaborava a Doutrina de Segurança Nacional (HOLANDA, [I967] 2008b). Não casualmente, o célebre prefácio de Antonio Candido para a quinta edição de Raízes do Brasil (I969) fora escrito no mesmo I967 - principal peça, à parte as mudanças no texto, de reabilitação do ensaio em novo contexto, peça que, conforme já exaustivamente estudado, conforma a (re)leitura progressista do clássico de 1936 (cf. HOLANDA, 2016). Buarque de Holanda em breve se aposentaria - pedido realizado, ainda segundo a "cronologia", em abril de I969-,

2 Segundo depoimento de Maria Amélia, esposa, os “Apontamentos para a cronologia de S." foram para ela ditados de memória pelo historiador, a princípio como suporte para a introdução biográfica que preparava Francisco de Assis Barbosa para a edição venezuelana de Visão do Paraíso (I987). Suporte memorialístico, serviu de base para outros esboços biográficos, do tipo “vida e obra”, como, mais recente, o roteiro de Raízes do Brasil: cinebiografia de Sérgio Buarque de Holanda, dirigida por Nelson Pereira dos Santos (2004). Ganhou, enfim, publicação em edição comemorativa de Raízes do Brasil (HOLANDA, M. A. B., [I979] 2006). 
solidário aos colegas aposentados compulsoriamente por força do Ato Institucional n. 5 (AI-5), de dezembro do interminável e já cinquentenário ano de I9683.

O tema da conferência não lhe fora demandado pelos estudantes, como havia sido no ano precedente à sua enunciação. A "aula" a que ele se refere na citação anterior fora, segundo consta no anexo, a aula inaugural "do ano atrasado", para os estudantes de História da USP, que o convocaram a falar sobre a noção de história, em função de um desconforto sentido relativamente aos colegas da Sociologia. Dizia ele, na oportunidade: "o fato da História resistir mais do que outras ciências ao enquadramento em sistemas fixos, o que denotaria a rigor sua maior complexidade, passa a ser considerado por muitos uma deficiência, uma espécie de tara quase vergonhosa" (HOLANDA, I96-, anexo, p. 2). Agora, nessa nova ocasião, para o "centro de estudos Taunay”, órgão estudantil do mesmo curso de História da USP, a situação era um pouco diferente, mas ainda assim preferiu Buarque de Holanda permanecer na "história teórica", conforme segue:

Como agora os estudantes do Centro de Estudos Históricos Afonso de Taunay renunciaram generosamente a escolher um tema, deixando-o a minha discrição, senti-me com ânimo, não para repisar os mesmos argumentos, já que não se impõe agora a posição polêmica, mas para indicar o reverso da medalha. (HOLANDA, I96-, anexo, p. I-2).

Não dispomos do texto da aula inaugural "do ano atrasado" para fins de comparação de qual seria o verso de tal medalha. De qualquer maneira, nessa palestra que agora vem a público, o que se encontra é um ensaio de epistemologia da história, uma tomada de posição epistêmica no campo historiográfico do momento. Para Buarque de Holanda, pois, "já não é possível apenas escrever história, é preciso saber refletir, e refletir demais sobre a história, sob pena de permanecer na rotina" (HOLANDA, I96-, anexo, p. 3). O historiador então trabalha, sem desprezar a interdisciplinaridade, um delineamento de fronteira disciplinar, ou, melhor, uma proposição quanto à singularidade da história entre as ciências sociais, considerando também a clivagem interna à disciplina histórica, diante do advento da história serial e sua pesquisa das regularidades.

O esboço da palestra é, também, indicador bastante claro de inclinações ou antipatias do autor, atenuadas ou excluídas na versão final. Nenhuma das remissões

3 Outro posicionamento público do historiador seria visto apenas em I978, quando ajudou a organizar e assumiu a vice-presidência do Centro Brasil Democrático (Cebrade), e nessa condição emitiu diversas declarações críticas da abertura a conta-gotas. Em uma delas, disse que em I968, ano da "consolidação da Revolução", abortaram-se projetos na universidade: "mais prejudicadas foram as ciências sociais e a filosofia, liquidaram com tudo" (HOLANDA et al., [I977] 2009b, p. IO2). Dois anos depois, I980, observou que a expansão da pós-graduação, ocorrida na década anterior, poderia ter sido ainda mais produtiva não fosse seu caráter autoritário. Nesse depoimento, um argumento, ainda que a posteriori, muito contundente sobre a aposentadoria: "Quis que os registros departamentais registrassem [sic] os atos arbitrários que estavam sendo praticados, uma vez que não havia imprensa livre onde fazê-lo. Assim, eu fiz questão de lavrar o meu protesto lá" (Holanda, [I982] 2009d, p. 208). 
ao rascunho aqui realizadas se encontra depois, tão abertamente, no texto definitivo. No essencial, contudo, os argumentos arrolados são os mesmos, em oposição à ambição de cientificização da história. Não se trata, por outro lado, um elogio ingênuo do historicismo, nem uma exclusão dos métodos sociológicos e quantitativos, mas um engajamento pela historicidade da história, traço constitutivo essencial de sua singularidade epistêmica. Era, pois, seu desacordo com o estruturalismo, em história representado pela longue durée de Fernand Braudel (I902-I985), que Buarque de Holanda exprimia na palestra. O rascunho é ainda mais explícito quanto a isso, e o autor inclusive sugere uma "volta ao acontecimento", apesar da impopularidade da expressão, ocasionada, segundo ele, por se prestar facilmente à confusão com o fetiche da precisão de datas.

O método da longa duração implicaria, ao cabo, que a sociedade se transforma através de fases que obedecem, de certo modo, a uma necessidade inexorável. O que aqui se chamaria dinâmico é exatamente o que em outras ciências se chama estático, obediente a algum esquema relativamente fixo. (HOLANDA, I96-, anexo, p. 8).

Isso tudo, portanto, justo no momento, a década de I960, de apogeu do paradigma estruturalista ${ }^{4} \mathrm{e}$, particularmente, da correlata longa duração braudeliana, concepção internacionalmente dominante na disciplina histórica, inclusive entre nós, a partir da USP, onde Braudel fizera discípulos, como Eurípedes Simões de Paula (I9IO-I977), fundador da Revista de História (USP), e Eduardo d'Oliveira França (I9I7-2003), com quem, este último, Buarque de Holanda debatera alguns anos antes 5 . Nosso autor, aliás, certa vez revelou não possuir muitas afinidades com o grupo dominante do departamento (HOLANDA, 2009c, p. 189). Maria Odila Dias, ex-assistente e discípula de Buarque de Holanda, mais tarde apontou também que havia alguma resistência de Eurípedes Simões de Paula e de Eduardo d'Oliveira França às sugestões e indicações do autor de Visão do Paraíso para as atividades departamentais (DIAS, 2002, p. I88).

Polêmica abertamente declarada, contudo, apenas nos anos I970, com Carlos Guilherme Mota ${ }^{6}$, que Eduardo França havia orientado no mestrado e no doutorado. Mais conhecido por sua tese de livre-docência, Ideologia da cultura brasileira (I977),

4 O ano de I966 representa, sobretudo com a publicação de Les mots et les choses, de Michel Foucault (I926-I984), o ponto culminante da "febre estruturalista”. La Méditerranée de Braudel é republicado, em segunda edição, nesse mesmo ano (cf. DOSSE, I993, p. 356).

5 Anteriormente, assistente de Braudel junto à cátedra de História da Civilização, Eduardo d’Oliveira França assumiu em I95I, por concurso, em que defendeu Portugal na época da Restauração, cuja banca examinadora contou com a presença de Buarque de Holanda, a cátedra de História da Civilização Moderna e Contemporânea. Em I958, França, por sua vez, compôs o júri do concurso em que Buarque de Holanda, com Visão do Paraíso: os motivos edênicos no descobrimento e colonização do Brasil (I959), conquistou a cátedra de História da Civilização Brasileira. Não sem divergências, em ambas as situações, sendo ainda que Buarque de Holanda publicou ensaio crítico no Diário Carioca (“Ainda o Barroco", I952). O núcleo do debate, conforme reconstituição recente, era "o limite entre o medieval e o moderno na história de Portugal e, por extensão, do Brasil” (cf. NICODEMO, 2008, p. II2).

6 Entre outras, as principais peças da polêmica são as seguintes: Holanda, (I973) 20IIf; Mota, 2010. 
Carlos Guilherme Mota já em I968, ainda candidato ao doutorado, organizava o livro Brasil em perspectiva, com prefácio do catedrático de filosofia João Cruz Costa (I904-I978) e participação, entre outros, de Fernando Novais e Emilia Viotti da Costa (I928-20I7). Mota mobilizava a referência de Braudel, também evocado no prefácio de Cruz Costa, a fim de justificar as pretensões científicas da coletânea: "Pretende lembrar, entre outras coisas, que há, em curso, uma história profunda, lenta, silenciosa, uma história das estruturas. Diversa de uma história de superfície, rápida, leve, no dia a dia, uma história dos acontecimentos". Brasil em perspectiva integrava a coleção Corpo e Alma do Brasil, coordenada por Fernando Henrique Cardoso na mesma editora Difel da CHGCB, de Buarque de Holanda. Este, em outra ocasião, ao rememorar um antigo ensaio homônimo, de I935, ironizou: "O título deve ser sugestivo, pois foi dado posteriormente a uma coleção, hoje vitoriosa, de estudos brasileiros que dirige Fernando Henrique Cardoso: chamou-se Corpo e Alma do Brasil" (HOLANDA, I979, p. 30). Não se deve, por certo, reduzir a noção de história expressa na palestra de fins dos anos I960 a essas supostas pequenas rivalidades, que, à exceção talvez do debate com Mota, não acabaram em combates ou em rupturas, mas não deixa de importar a consideração desse contexto intelectual-institucional em que se apinhavam concepções relativamente diversas.

Muito pouco explorado na fortuna crítica buarquiana, provavelmente dada sua situação de ineditismo, o texto da conferência que ora apresento, versando exclusivamente sobre epistemologia da história, é um produto relativamente raro na trajetória do autor, fruto de longa reflexão, que parte das próprias práticas historiográficas, em torno de uma concepção que ele passa a expor e defender nesses e nos anos seguintes. Antes, fim dos anos I940 e início de I950, havia publicado ensaios na imprensa a respeito das inovações dos Annales ${ }^{8}$ - de quem, sobretudo na figura de Lucien Febvre (I878-I956), se aproximava no período (HOLANDA, I950) -, balanços bibliográficos e de crítica historiográfica (HOLANDA, [I948] 20IIa; [I967] 2008a), ou ainda, propostas de (re)definição do papel social do "verdadeiro historiador" (HOLANDA, [I948] I996a; [I952] 20IIe), ocupado das coisas de seu tempo. Tais ensaios, ainda que os fizesse desde o espaço da crítica literária, contribuíram para a profissionalização do ofício. Depois da palestra citada, algumas das ideias nela expressas Buarque de Holanda desenvolverá em outros ensaios, como na já citada polêmica com Mota, "Sobre uma doença infantil da historiografia", quando procura apontar a historicidade também dos próprios conceitos históricos. Ainda, e principalmente, porque culminante dessa longa reflexão, no ensaio sobre "O atual e o inatual em Leopold von Ranke”, original de I974, na Revista de História (USP). Nesse, Buarque de Holanda, a propósito de Ranke (I795-I886), realiza uma importante peça de história da historiografia, cobrindo o historicismo do Oitocentos até a história dos conceitos de Reinhart Koselleck (I923-2006), passando pelos Annales, pelo debate do pós-guerra sobre continuidade, descontinuidade e teleologia na história, além de

7 O texto citado foi o da aula inaugural de Braudel no Collège de France, "Positions de l'histoire en I950" (cf. MOTA, I968, p. II).

8 Entre outros: Holanda, (I950) 20Irb; (I950) 20IIc. 
comentar os esforços de Braudel em caracterizar a "história estrutural" então em voga. Segue este trecho, naquilo que concorda com a palestra destacada.

A dificuldade maior que neste caso se apresenta, muito maior ainda do que a proporcionada pelos problemas relacionados com a continuidade-descontinuidade, consiste no fato de a própria conceituação de estrutura variar quase tanto quanto as disciplinas ou até quanto aos próprios autores que costumam recorrer aos seus préstimos. [...] Quase sempre resultam de teorias elaboradas numa perspectiva estática, quando muito estável, que não se integram no tempo senão com dificuldade. Nessas condições podem tornar-se tão incompatíveis com o processo histórico que é o caso de perguntar se a expressão "história estrutural" não encerra um contrassenso. Para superar a incompatibilidade seria mister redefinir o conceito, de modo a que o tempo cesse de ser exterior às realidades estudadas e se confunda enfim com a própria estrutura. Foi um pouco o que fez Fernand Braudel quando quis historizar esse conceito (HOLANDA, I974).

De retorno ao objeto propriamente dito de nossa apresentação, a exceção quanto ao uso da palestra na análise do pensamento histórico buarquiano é Maria Odila Dias, que a comentou em pelo menos duas ocasiões, sobre o estilo, o método e a concepção de história em Buarque de Holanda. A principal delas, no texto "Sérgio Buarque de Holanda, historiador”, de I985, que serve de introdução a uma coletânea póstuma de excertos da sua obra. Entre homenagens e estudos póstumos na década de I980, fora realizado por uma discípula direta, então professora titular de História do Brasil na USP, texto que, cobrindo analiticamente suas obras desde Raízes do Brasil até Do Império à República (I972), entendo como um dos suportes de cristalização da imagem do autor na memória da disciplina. A citação:

[...] Compartilhava com Croce a aversão aos ismos: capitalismo, mercantilismo, imperialismo pareciam-lhe termos 'que, por serem imprecisos, mais dissipavam, do que aguçavam nossa visão do passado' (conferência de I960 para os estudantes do Centro de Estudos Históricos Afonso Taunay. Original datilografado). (DIAS, I985, p. 23).

A outra, no texto "Estilo e método na obra de Sérgio Buarque de Holanda", publicado no livro Sérgio Buarque de Holanda: vida e obra (I988), trabalho conjunto do IEB com o Arquivo Público de São Paulo: "Pode-se dizer que toda sua obra foi construída em torno do conceito de tempo, continuidade e mudança no processo de vir a ser. Para Sérgio Buarque de Holanda a história era o conteúdo vivo das ciências humanas, reconstruídas do prisma de sua temporalidade” (DIAS, I988, p. 75). E a conferência, citada em nota ao fim desse parágrafo. A propósito, Sérgio Buarque de Holanda: vida e obra possui um minucioso levantamento biobibliográfico do historiador homenageado, organizado por Rosemarie Erika Horch (I930-2008). Não consta, porém, referência ao texto da palestra. Em levantamento mais recente, igualmente, nada consta (CARVALHO; NEUMANN-WOOD, 2008). O professor Arthur Assis, da Universidade de Brasília (UnB), em bela interpretação teórica de Do Império à República, cita, em nota de rodapé, as palavras finais da palestra como sinal de "reconhecimento", por Buarque de Holanda, "da importância da função orientadora 
do conhecimento histórico" (ASSIS, 20I0, p. I20, nota 37). De minha parte, a análise do documento se deu em função da escrita de si do historiador (CARVALHO, 20I7, p. I3I-I37), o relato em primeira pessoa que retoma sua trajetória, de modo a, em discurso sobre a disciplina histórica, configurar a identidade de historiador - naquele espaço, para recorrer a Nora (I987, p. 7), entre a história que o historiador produz e a história que o faz historiador. Como geralmente ocorre em textos de historiografia (entendida como teoria e história da história), no mais das vezes indiretamente, vemos um posicionamento do autor na tradição disciplinar. No caso de Buarque de Holanda, apesar da referência privilegiada, na conferência que segue, ao historicismo e à historicidade da história, trata-se de uma inscrição complexa, criativa, que mistura o melhor das tradições da escola histórica alemã e dos Annales, sobretudo da dita primeira geração. Assim, o autor confere maior dinâmica no tempo presente como verdadeiro manancial de sentido da história, de onde parte o problema e para onde retorna o historiador em uma dialógica compreensiva entre os tempos.

Foram inseridas algumas notas ao documento original no intuito de prestar alguns esclarecimentos sobre momentos da trajetória do autor, concernentes primeiro ao ambiente universitário em que foi produzido, e no sentido de penetrar os debates propostos na conferência, identificando seus interlocutores e acentuando a profundidade das concepções então discutidas. Estas foram as diretivas aplicadas diante do impulso frustrado de comentar todas as referências, nomes, obras e termos explorados pelo historiador -, as quais exponho na tentativa de reduzir o grau de inevitável arbítrio no feitio das notas.

Foi preservado, o mais fielmente possível, o original datilografado com as revisões manuscritas. Para tanto, a solução adotada foi utilizar o itálico para os acréscimos manuscritos e o [tachado entre colehetes] para os rabiscos em trechos suprimidos. Algumas palavras ou pequenos trechos foram, possivelmente, em uma primeira revisão tipográfica, rasurados à máquina pelo autor, de modo que são ilegíveis e, por isso, foram na transcrição ignorados, sem qualquer prejuízo de compreensão do texto. As palavras que aparecem, no original do autor, sublinhadas assim permaneceram. Entre colchetes ainda consta, acréscimo nosso, indicação da [paginação original] e, eventualmente, alguns [sic], que apontam lapsos gramaticais do autor, em termos de concordância ou de redundância. Algumas pequenas falhas da datilografia, como palavras com letra faltante, e vírgulas suprimidas ou inseridas manualmente, não foram sinalizadas, mas sim corrigidas as palavras e mantidas as vírgulas acrescidas. Por fim, foi realizada atualização segundo o último acordo ortográfico.

Deixamos a palavra, enfim, algo bem mais interessante, a Sérgio Buarque de Holanda. 


\section{"História”, palestra de SÉrgio Buarque de Holanda no Centro de Estudos Históricos Afonso Taunay, UNIVERSIDAde de São PAUlo (CEHAT/USP) (I967-I969)}

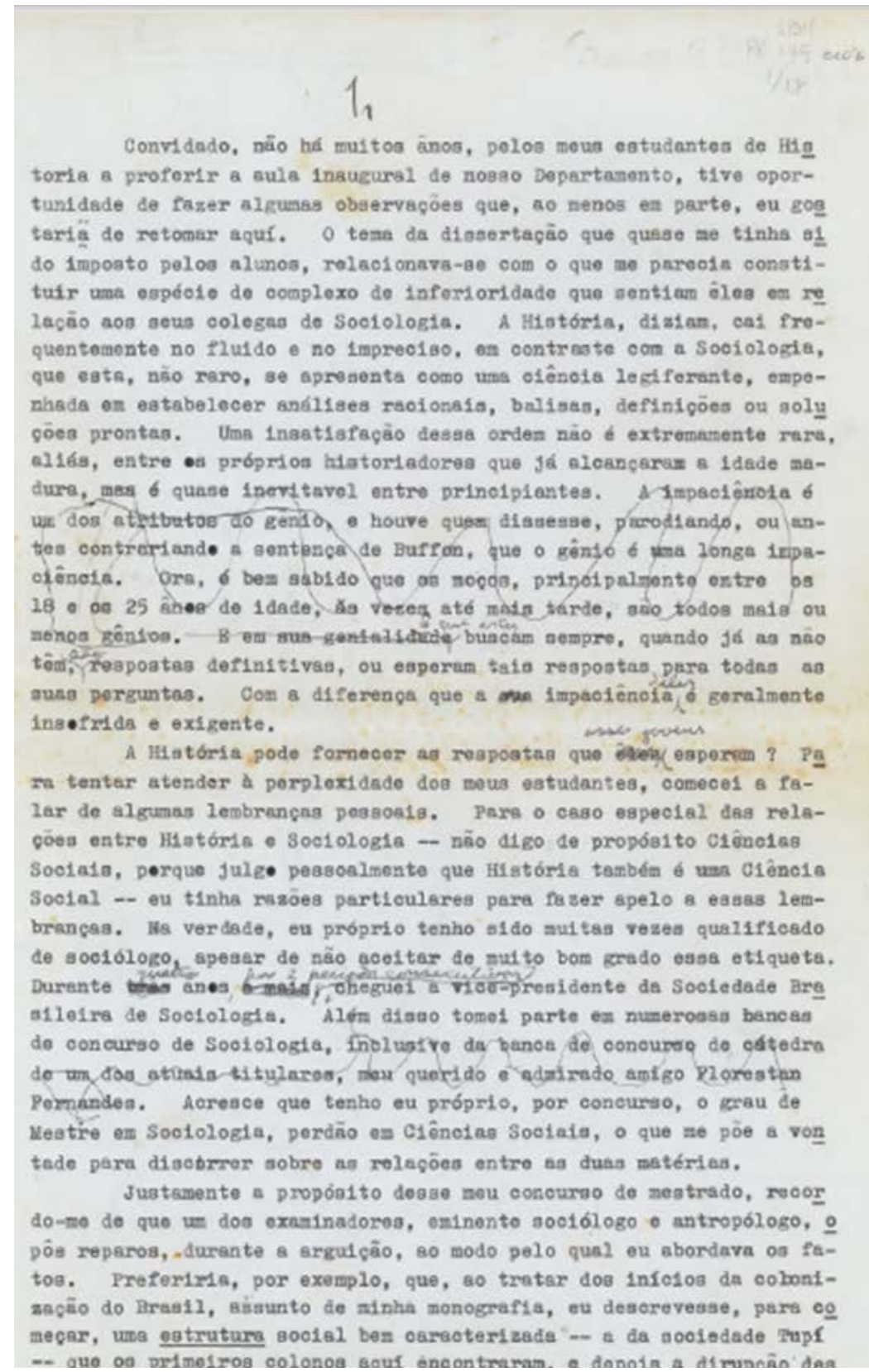

Figura I - Reprodução eletrônica da primeira página datilografada da palestra "História", de Sérgio Buarque de Holanda, no CEHAT da USP, entre I967 e I969. Fonte: Siarq/Unicamp, Fundo SBH: Pi I79 
Convidado, não há muitos anos, pelos meus estudantes de História a proferir a aula inaugural de nosso Departamento", tive oportunidade de fazer algumas observações que, ao menos em parte, eu gostaria de retomar aqui. O tema da dissertação que quase me tinha sido imposto pelos alunos, relacionava-se com o que me parecia constituir uma espécie de complexo de inferioridade que sentiam eles em relação aos seus colegas de Sociologia. A História, diziam, cai frequentemente no fluido e no impreciso, em contraste com a Sociologia, que esta, não raro, se apresenta como uma ciência legiferante, empenhada em estabelecer análises racionais, balizas, definições ou soluções prontas. Uma insatisfação dessa ordem não é extremamente rara, aliás, entre os próprios historiadores que já alcançaram a idade madura, mas é quase inevitável entre principiantes. [A impaciência é um dos atributos do gênioe houve quem dissesse, parodiando, ou antes contrariando a sentença de Buffon, que o gênio é uma longa impaciência. Ora, é bem sabido que os moços, principalmente entre os 18 e os 25 anos de idade, às vezes até mais tarde, são todos mais ou menos gênios. Eem sua genialidade] $O$ que estes buscam sempre, quando já as não têm, são respostas definitivas, ou esperam tais respostas para todas as suas perguntas. Com a diferença que a [sua] impaciência deles é geralmente insofrida e exigente.

A História pode fornecer as respostas que [eles] esses jovens esperam? Para tentar atender à perplexidade dos meus estudantes, comecei a falar de algumas lembranças pessoais. Para o caso especial das relações entre História e Sociologia - não digo de propósito Ciências Sociais, porque julgo pessoalmente que História também é uma Ciência Social - eu tinha razões particulares para fazer apelo a essas lembranças. Na verdade, eu próprio tenho sido muitas vezes qualificado de sociólogo, apesar de

9 Sérgio Buarque de Holanda assumiu em fins de I956, na então Faculdade de Filosofia, Ciências e Letras (FFCL) da Universidade de São Paulo (USP), a regência da cátedra de História da Civilização Brasileira, a princípio interinamente, a convite do professor Eurípedes Simões de Paula (I9Io-I977), então diretor da FFCL, devido a complicações de saúde do titular, Alfredo Ellis Jr. (I896-I974). Somente em I958, enfim, ocorreu concurso, no qual foi aprovado com a tese Visão do Paraíso: motivos edênicos na descoberta e colonização do Brasil, escrita segundo o autor em poucos meses, a partir de material já produzido para um projeto de história do barroco no Brasil. A banca examinadora fora composta por dois professores da casa, Eurípedes Simões de Paula (presidente) e Eduardo d'Oliveira França (I9I5-2003), Hélio Viana (I908-I972) e Afonso Arinos de Melo Franco (I905-I990), da Universidade do Brasil (RI), e José Wanderley Pinho (I890-I967), da Universidade da Bahia. No ano seguinte, a obra foi publicada em livro pela casa editora de José Olympio (I902-I990), na mesma coleção Documentos Brasileiros (n. I07) de Raízes do Brasil. Ao menos dois legados de Buarque de Holanda, frutos de sua atuação na universidade paulista nos anos I960 em tela, merecem a lembrança: a Coleção História Geral da Civilização Brasileira, que dirigiu entre I960 e I972, e a criação, em I962, do multidisciplinar Instituto de Estudos Brasileiros, que, à exceção da sociologia, ausente do conselho de administração, por "não conjugar o ensino à pesquisa de assuntos brasileiros”, agrupava catedráticos de diversas disciplinas, da geografia à economia, da antropologia à arquitetura e, claro, história e literatura brasileiras (CALDEIRA, 2002, p. 65). 
não aceitar de muito bom grado essa etiqueta ${ }^{\mathrm{Io}}$. Durante [três] quatro anos [e mais], por 2 períodos consecutivos, cheguei a vice-presidente da Sociedade Brasileira de Sociologia. Além disso, tomei parte em numerosas bancas de concurso de Sociologia. [, inclusive da banea de concurso de cátedra de um dos atuais titulares, meu querido eadmirado amigo Florestan Fernandes]. Acresce que tenho eu próprio, por concurso, o grau de Mestre em Sociologia, perdão em Ciências Sociais ${ }^{\text {II }}$, o que me põe a vontade para discorrer sobre as relações entre as duas matérias.

Justamente a propósito desse meu concurso de mestrado, recordo-me de que um dos examinadores, eminente sociólogo e antropólogo, opôs reparos, durante a arguição ${ }^{\mathrm{I2}}$, ao modo pelo qual eu abordava os fatos. Preferiria, por exemplo, que, ao tratar dos inícios da colonização do Brasil, assunto de minha monografia ${ }^{\mathrm{T3}}$, eu descrevesse, para começar, uma estrutura social bem caracterizada - a da sociedade Tupi - que os primeiros colonos aqui encontraram, e depois a dirupção dessa estrutura ocorrida com o advento do homem branco. Objetei-lhe [p. 2 do manuscrito] que semelhante argumento era próprio de sociólogos ou antropologistas, pois que em História as estruturas, quando mal se insinuam já são [imediatamente] quase ao mesmo tempo superadas. História é mobilidade constante. Tentar sujeitá-la a estruturas e dirupções é o mesmo que pretender introduzir freios artificiais nessa mobilidade ou, como já houve quem o dissesse, é reduzi-la a [uma sucessão] um cortejo de imobilidades. [Em outras palavras é querer substituir o cinema pela lanterna mágiea.]

Io Logo após o concurso, Buarque de Holanda negou enfaticamente em entrevista a condição a ele atribuída de sociólogo. Perguntado sobre os rumos da sociologia brasileira, disse, simplesmente: "Não posso responder. Não me considero sociólogo e sim historiador" (HOLANDA, [I959] 2009a, p. 65). Sinal, talvez, do aprofundamento do processo de especialização acadêmica e dele próprio enquanto intelectual, a necessidade de delimitação de uma identidade intelectual e disciplinar. Onze anos antes, pois, havia escrito o ensaio "Novos rumos da Sociologia” (I948) para o Diário de Notícias, do Rio de Janeiro (HOLANDA, 20Ira).

II Pouco antes do concurso à cátedra, em julho de I958, Buarque de Holanda, meio às pressas, defendeu na Escola Livre de Sociologia e Política (ELSP), em São Paulo, onde inclusive lecionou entre I954 e I956, uma dissertação para, na ausência de titulação acadêmica, obtenção do grau de mestre e habilitação para concorrer à cátedra.

I2 A banca examinadora foi composta por Octavio da Costa Eduardo (orientador), Odilon Nogueira de Matos (I9I6-2008), Antonio Rubbo Müller (I9II-I987), Fernando Altenfelder Silva e Herbert Baldus (I899-I970), o provável arguidor referido. Baldus, alemão, etnólogo, radicado definitivamente no Brasil após a chegada dos nazistas ao poder na Alemanha em I933, tornara-se catedrático na própria ELSP em I939, e havia dirigido o Museu Paulista, a convite de Buarque de Holanda, durante o afastamento deste enquanto esteve regente da cátedra de estudos brasileiros da Universidade de Roma (I952-I954) (CALDEIRA, I998; FRANÇOZO, 2005).

I3 A dissertação até pouco tempo permaneceu na obscuridade, tanto que o texto, citado na nota anterior, de Caldeira (I998, p. 230) lamentava não tê-la encontrado na biblioteca da ELSP. Foi "redescoberto" durante os trabalhos da comissão organizadora das comemorações do centenário de Buarque de Holanda (2002), presidida na Unicamp - instituição depositária do acervo pessoal de Buarque de Holanda desde I983, ano após sua morte - pelo professor Edgard de Decca (I946-2016). Intitula-se "Elementos formadores da sociedade portuguesa na época dos descobrimentos” e permanece inédita, localizável no Siarq/Unicamp, Fundo SBH: Série produção intelectual: Pi I75. Ver também: Nicodemo (2008, p. I62-I69), sobre a dissertação de Buarque de Holanda, ao lado de Visão do Paraíso. 
Mais tarde, examinando [sic] num concurso de Sociologia em nossa Faculdade ${ }^{\mathrm{I} 4}$, tive ocasião de lembrar a um colega essa diferença que separa os historiadores de certos sociólogos. Fiz questão de frisar: certos sociólogos. Replicou-me ele que, procurando acusar a Sociologia de ater-se a conceitos rígidos e deixar unicamente a [sic] História a possibilidade de abordar [e] um movimento, que não se deixa amarrar em tais conceitos, eu queria nada menos do que guardar para a História a parte melhor e [abandonar] deixar o bagaço à Sociologia. Acabei por admitir que os que fazer [sic] boa sociologia histórica, e os há numerosos e excelentes, faz [sic] também boa história, e o colega concordou ${ }^{\text {I5 }}$.

I4 Cabe ao menos indicar alguns momentos, todos na década de I960, em que Buarque de Holanda tomou parte na Sociologia: primeiro, como ele mesmo chegou a lembrar ao preparar a citada palestra, mas por fim resolveu excluir da versão que supomos mais próxima daquela efetivamente apresentada, participou em I964 do concurso que confirmaria a cátedra de Sociologia I ao “querido e admirado amigo" Florestan Fernandes (I920-I995) - no mesmo ano em que avaliou o doutorado de Maria Sylvia de Carvalho Franco, e mesmo já antes, I96I, havia contribuído na avaliação das teses de Fernando Henrique Cardoso e de Octavio Ianni (I926-2004). Segundo, o concurso vencido por Fernando Henrique Cardoso em I968 para a cadeira de Política, após o falecimento do antigo titular, Lourival Gomes Machado (I9I7-I967). Buarque de Holanda, segundo Spirandelli (2008, p. IOI), teria chegado a "torcer" pela vitória de Fernando Henrique Cardoso na disputa com a até então assistente de Lourival Machado, Paula Beiguelman (I926-2009). Esse concurso, conforme W. M. Romão (2006, p. I37, nota 64), fora muito conturbado, devido às tensões internas à Congregação da FFCL e às demandas políticas do movimento estudantil de I968 sobre a mesma Congregação, tensões essas particularmente relativas às posições radicais tomadas por Florestan Fernandes, tanto simpático às demandas dos estudantes quanto - cioso da expansão da área de influência de seu grupo - crítico da decisão inicial da Congregação, que a princípio não o incluíra entre os representantes desta junto à comissão julgadora do concurso.

I5 Talvez seja à defesa de tese de Maria Sylvia de Carvalho Franco que possamos vincular essas palavras de Buarque de Holanda sobre história e sociologia pronunciadas aos estudantes reunidos no CEHAT. Além dele e do diretor da tese, Florestan Fernandes, estiveram reunidos à banca Octávio Ianni, Antonio Candido (I9I8-20I7) e Francisco Iglésias (I923-I999). Franco, ainda que sua temática integrasse as preocupações da cadeira à qual esteve ligada, divergia do orientador Florestan Fernandes e de seu primeiro assistente, Fernando Henrique Cardoso, basicamente, de acordo com L. C. Jackson (2007, p. I26), quanto ao conceito de escravidão. Para ela, a escravidão não era incompatível com um capitalismo praticado no Brasil, dada sua orientação para o mercado externo, desde o início da colonização. Além disso, Jackson afirma, o posicionamento da autora pode estar ligado à disputa aberta pela vaga de primeiro assistente da cadeira de Sociologia I, com o afastamento de Fernando Henrique Cardoso, no exílio em I964. A tese foi publicada oito anos depois, com apoio de Antonio Candido e Sérgio Buarque de Holanda, pelo IEB, sob o título Homens livres na ordem escravocrata (I969). Dos debates em torno de sua tese partiram, segundo hipótese de A. Botelho (2013), as reflexões da autora sobre as tensões entre teoria e história na sociologia, expressas em sua tese de livre-docência, O moderno e suas diferenças (I970). Nas palavras de Botelho (20I3, p. 332): "Maria Sylvia de Carvalho Franco recoloca em questão o problema da historicidade da vida social para a sociologia, em uma análise fina que busca esclarecer as conexões de sentido que o processo histórico-social engendra entre categorias e relações sociais”. Importa menos, aqui, especular sobre se Buarque de Holanda teria dito tais palavras nessa determinada banca que propriamente perceber alguma afinidade com o pensamento de Maria Sylvia de Carvalho Franco, que, ainda de acordo com Botelho (20I3, p. 333), frisava o sentido histórico das construções ideal-típicas weberianas, contrária à conversão destas em generalizações e modelos abstratos - tudo aquilo a que Buarque de Holanda, desde muito cedo em sua trajetória intelectual, marcou oposição, e que exprime na conferência comentada. 
Quando me referia há pouco a "certa Sociologia”, frisando bem o certa, estava pensando em particular em certos representantes da escola francesa de Durkheim, que às vezes tinham em escassa conta a História, só por isso que, em contraste com as demais ciências, ela parece inacessível ao império das leis e dos esquemas precisos ${ }^{\mathrm{I} 6}$. Seria fácil responder-lhes que esse afã de querer esquematizar, dividir, contabilizar a qualquer preço todos os aspectos, ainda os mais recalcitrantes, de um mundo naturalmente movediço, não ajuda a dar maior precisão ao discurso histórico. O que dele resultaria, quando muito, seria uma imprecisão mais metódica e mais minuciosa, por isso mais enganadora. E ao raciocínio dos que acusam a historiografia de apresentar-se frequentemente como um saber mais empírico do que formal, diria eu que é esse o raciocínio da raposa, daquela célebre raposa de La Fontaine que desdenha o racimo de belas uvas só porque [eseapa] escapou às suas garras.

Ao tempo em que eu dizia dessas coisas aos meus estudantes ainda não tinha o renome que hoje alcançou e nem se achava plenamente constituído o moderno estruturalismo. Sabemos [hoje] agora como essa escola ou, se quiserem, esse método, se vai impavidamente alastrando sobre as mais inesperadas áreas, pois partindo da Antropologia ou, a rigor, da Linguística atual, que já alcançou um nível de formalização comparável ao das ciências naturais, passou a invadir, para citar um exemplo, até as Belas Letras e já começa a ameaçar a Historiografia.

I6 David Émile Durkheim (I858-I9I7), normalien e agregé de filosofia, professor de ciência social e educação na Universidade de Bordeaux em I887, ficou consagrado como o chefe da chamada escola sociológica francesa. Esta, organizada em torno da revista L'Année Sociologique, fundada em I898, e que agrupava nomes logo também consagrados, como os de Marcel Mauss (I872-I950), Maurice Halbwachs (I877-I945) e François Simiand (1873-1935). Suas teses, tratando os fatos sociais como coisas e afirmando a autonomia destes para a explicação do social pelo social, são condensadas em "As regras do método sociológico" (1895) e aplicadas aos temas da divisão social do trabalho e do suicídio. Durkheim é reconhecido, sobretudo, como o principal agente impulsionador da institucionalização universitária da sociologia entre o fim do século XIX e início do XX, contexto este, o da Terceira República, de profunda reestruturação, no sentido de sua autonomização, do sistema educacional e universitário na França. Nesse percurso, o grupo de Durkheim enfrentou a concorrência de correntes sociológicas tais quais o organicismo de René Worms (I869-I926), à frente da Revue Internationale de Sociologie, fundada em I893, e a psicologia social de Gabriel Tarde (I843-I904). No campo mais vasto das ciências sociais, a história era a disciplina concorrente na sua ambição de hegemonia. Daí a famosa investida de Simiand (I960) contra a história tradicional (política, individual e cronológica) em "Méthode historique et science social: étude critique à propos des ouvrages récents de M. Lacombe et de M. Seignobos", nas páginas da Revue de synthèse historique, em I903. O texto foi (re)publicado nos Annales em I960, contando apenas pequena nota de Braudel, sinalizando a sua importância para o diálogo da história com as ciências sociais, diálogo apresentado, aliás, como a razão de ser e a finalidade da própria revista. O texto era então mobilizado pelos Annales, segundo interpretação de J. Revel, como se constituísse uma espécie de prefiguração do programa de Marc Bloch (I886-I944) e Lucien Febvre (I878-I956), em função agora da ofensiva do estruturalismo anti-historicista (REVEL, 2007, p. I26). 
Para os estruturalistas, que tiram suas origens de Durkheim ${ }^{17}$ e, através do sociólogo francês, do positivismo do século passado, em particular do positivismo de Augusto Comte $^{\mathrm{I8}}$, torna-se possível estudar os homens primitivos mais ou menos como se [não passassem de] fossem formigas. E assim como as formigas podem ser estudadas e classificadas pelos naturalistas, aquela humanidade arcaica pode ser estudada e

I7 Durkheim era percebido de forma semelhante em outros textos de época, como o de Fernand Braudel (I902-I985), "História e Sociologia" (I965), na Revista de História - tradução do capítulo 4, volume I, do Traité de Sociologie (I958), direção de Georges Gurvitch (I894-I965). Dizia então Braudel: "Entendo aqui por sociologia, muitas vezes, senão quase sempre, aquela ciência global que Émile Durkheim e François Simiand pretendiam constituir no começo deste século - aquela ciência que ainda não é, mas para a qual não deixará de tender, ainda que nunca venha a realizar plenamente tal objetivo" (Braudel, I965a, p. II). No número seguinte da Revista de História, ainda em I965, encontramos a tradução do célebre ensaio, representativo da reação da história ao desafio estruturalista, "História e Ciências Sociais: a longa duração”: “Boa ou má [a palavra estrutura], é a que domina os problemas da longa duração” (Braudel, I965b, p. 268). Em sua história do estruturalismo, François Dosse assevera que o “durkheimianismo" teve um "segundo alento" na segunda metade do século XX, com a obra de Pierre Bourdieu (I930-2002), cujo horizonte teórico, pelo menos até os anos I970, seria o estruturalismo (DOSSE, I994, p. 85). Jacques Revel, igualmente, nota a parentela entre o momento estruturalista e o momento durkheimiano anterior, ambos empenhados em reunir as ciências sociais em torno de uma proposta metodológica unificada (REVEL, 2007, p. I20). De um ponto de vista diverso, Cristophe Charle questiona o recurso à memória da "antiga e ultrapassada" querela de I903 entre Simiand e Seignobos e assinala novas bases das relações de força entre as disciplinas a partir de Bourdieu, cuja relação com a história Charle considera mal conhecida (CHARLE, 20I4). Uma atenção renovada à "escola sociológica francesa" pode ser encontrada entre nós na Coleção Biblioteca Durkheimiana (Edusp), coordenada por Rafael Faraco Benthien e Raquel Weiss, cujo primeiro volume é a edição crítica do texto "O individualismo e os intelectuais", do próprio Durkheim (20I6).

I8 Auguste Comte (I798-I857), filósofo positivista de grande repercussão no Brasil - em fins do Oitocentos, entre o Império e a República -, é também conhecido como um dos precursores da sociologia, palavra da qual reclamava o título de inventor em seu Cours de philosophie positiviste, publicado em seis tomos, entre I832-I840, à margem das instituições universitárias. Nessa obra, Comte define, com base em uma filosofia da história, o estágio atual e culminante da humanidade, a era da ciência positiva, após as idades teológica e metafísica. No estado positivo, a ciência e a técnica, em busca das leis que determinam os fenômenos, psicológicos, naturais e históricos, fundamentam as relações políticas e sociais. Desse modo, entre as ciências, a sociologia ocupa o topo da hierarquia, vista em sua capacidade de sistematização e aplicação dos saberes. Em Raízes do Brasil, que em I967 chegava a sua quinta edição, a definitiva, Buarque de Holanda criticava os adeptos brasileiros da filosofia de Comte, Benjamin Constant (I836-I89I) à frente, qualificando-os “doutrinadores do tempo", que procuravam adaptar a realidade histórica brasileira às "definições irresistíveis e imperativas do sistema de Comte” (HOLANDA, 20I6, p. 278). O professor Ruy Galvão de Andrada Coelho (I920-I990), catedrático de Sociologia II após a saída de Fernando de Azevedo (I894-I974), defendera em I96I a tese de livre-docência O indivíduo e a sociedade na obra de Auguste Comte. Esse professor publicara em I969 na Revista de História o texto, originalmente pronunciado na Sociedade de Estudos Históricos em I967, “Sociologia e História”, que, remontando a Comte e a Durkheim, recupera o debate crítico entre as disciplinas e nos oferece boa medida da situação: "No momento que atravessamos, a Sociologia procura desvencilhar-se da obsessão estruturalista, para propor-se de novo aos problemas básicos da dinâmica social. Em tal conjuntura, a colaboração da História é essencial” (COELHO, I969, p. 24). 
classificada pelos antropólogos, que não se cansam de inventariar por exemplo o seu regime de castas, $o$ seu código totêmico, os seus grupos de parentesco, $a$ sua [p. 3] mitologia, articulando tudo isso em esquemas lógicos. Mas se [isso é] tal coisa se torna possível, é só por[que] se tratar de povos "sem história” - assim o admite o próprio Lévi -Strauss ${ }^{\text {I9 }}$, ou quando muito admite que a sua é uma história fria. É evidente que não se poderiam aplicar critérios semelhantes a homens como nós, que nos presumimos civilizados, pelo simples fato de termos um passado consciente, de termos e vivermos uma História, uma história quente, se é lícito dizer assim.

A espécie de mal-estar com que muito historiador enfrenta por vezes a necessidade, [muitas] tantas vezes inevitável, de recorrer a determinados conceitos que não passam, a bem dizer, de abstrações úteis, mas em todo caso [de] abstrações[;] que em seu estado puro só podem existir no mundo das ideias, bem pode ser exemplificada com o caso - mas devo dizer que é um caso extremo - que [pude encontrar] encontrei no volume correspondente ao século XVIII da História Econômica da Inglaterra dirigida por T. S. Ashton. O próprio Ashton, que é Professor Emérito na Universidade de Londres, afirma no prefácio a esse volume que não teve medo de desapontar muitos dos seus leitores, quando [evita] evitou abordar [eertas] algumas ideias da época tratada ou, melhor, reconstruções modernas dessas ideias, consagradas em denominações tais como as de Capitalismo, Mercantilismo, Imperialismo, pois confessa seu escasso gosto por essas palavras que lhe parecem imprecisas e feitas só para desvirtuar, não para aguçar, nossa visão do passado. Lembra que uma vez, em Oxford, se gabara de que nenhum vocábulo acabado em "ismo" haveria de aparecer em sua tese.

- [E]Nem mesmo batismo? retrucou um companheiro, com sua ironia bem oxoniense. Seria bem simples, comenta Ashton, substituir a palavra, dizendo, por exemplo, "cristianização". Mas não quis o historiador incorrer no pecado de vanglória e preferiu deixar as sílabas ofensivas.

I9 Foi dele, do antropólogo Claude Lévi-Strauss (I908-2009), que partiu o desafio estruturalista à disciplina histórica, no artigo "Histoire et Ethnologie" publicado em I949 na Revue de Métaphysique et de Morale em número (54) consagrado ao tema da história. Lévi-Strauss foi um dos professores franceses que integraram a missão de fundação da Universidade de São Paulo, tendo chegado ao país em I935, na “segunda leva” de jovens professores, ao lado de Braudel e outros, e permanecido no posto de professor de sociologia até I938. Segundo Fernanda Peixoto, a passagem pelo Brasil foi fundamental na construção de sua carreira futura de etnólogo: “O jovem agregé em filosofia, de perfil particular -não francês, não normalista, judeu e militante socialista -, é indicado por [Célestin] Bouglé [então diretor da École Normale Supérieure], durkheimiano fervoroso, para vir ao Brasil como professor. Em vários momentos, Lévi-Strauss afirma que a escolha de um aprendiz de etnologia avesso à tradição durkheimiana chocou-se de imediato com as intenções dos contratantes paulistas, imersos na influência comtiana e durkheimiana, e que desejavam um professor de sociologia herdeiro dessa tradição" (PEIXOTO, I998, p. 97). Contudo, a autora relativiza essa colocação autobiográfica de Lévi-Strauss, indicando outras razões para alguns desentendimentos com a Universidade, como a ênfase na pesquisa e a militância de esquerda, de modo que: "As afirmações referem-se a um contexto específico em que o jovem filósofo reclamava, dentre outras coisas, da ausência de trabalho de campo na escola sociológica francesa. Posteriormente, como bem sabemos, Lévi-Strauss não cansará de mencionar o seu débito intelectual em relação à produção durkheimiana e a dívida da etnologia para com a obra do mestre francês" (PEIXOTO, I998, p. 98). 
A esse caso, caso extremo, repito, pode-se contrapor o dos historiadores que, em fins do século passado e em princípios do atual, imaginaram e às vezes tentaram pôr em prática uma espécie de ciência teórica da História sujeita a leis tão inflexíveis como aquelas que a [presidem] parecem presidir as chamadas exatas. Inspiravam-se, como os sociólogos franceses de que falei, em modelos provenientes, em última análise, do positivismo comtiano ou também do spencerismo. [Sua] Tal ambição tinha, aliás, uma venerável genealogia, pois entre os seus antepassados podem inscrever-se, de um lado o racionalismo da era das Luzes, de outro o empirismo à maneira de Hume, para não ir mais longe. E o seu magnum opus bem poderia ser o Quadro Histórico dos Progressos do Espírito Humano, que Condorcet acabou de escrever em I794, já na prisão, e a Comissão de Instrução Pública da França revolucionária mandou publicar no dia I3 de Germinal do Ano III.

Não é raro que ainda em nossos dias se dissimule mal uma tendência semelhante, mesmo entre o grande público, ou entre os que não exercem habitualmente o ofício de historiador. E não [p. 4] parece excessivo dizer-se que também entre profissionais dos mais respeitáveis, essa tendência é suscetível de ganhar bom crédito, se convenientemente dosada e [bem] disfarçada. Significativo a respeito é o exemplo do monumental Estudo de História de Arnold Toynbee, que, principalmente no resumo feito por Sommervell, do texto original em doze compactos volumes, conseguiu, apesar da pesada erudição que carrega, converter-se em pouco tempo num autêntico best-seller. A felicidade de alguns dos achados do autor, como aquele do challenge and response (repto e réplica), por onde pareciam explicar-se em termos singelos muitos dos mais [profundos e] complicados mistérios que presidem ao engrandecimento, ao acaso, por vezes a fatal esclerose [de muitas] das civilizações, tudo servido por um admirável estilo literário, tinha como justificar largamente a aceitação geral da obra. De fato, não é de surpreender esse bom sucesso, pois muitas das fórmulas sugeridas traziam no bojo o prestígio natural dessas certezas apodíticas, que servem para embalar imaginações e dar descanso [a] às inteligências preguiçosas.

Não tardou muito, porém, e surgiram alguns historiadores desmancha-prazeres para pôr em dúvida a suposta virtude universal desses sugestivos esquemas de Toynbee. A verdade, mostravam eles, de forma irrefutável, é que os exemplos invocados pelo autor em apoio dos mesmos esquemas tinham sido arbitrariamente escolhidos dentre uma infinidade de outros que teimavam em insurgir-se contra eles. Seja como for, não há dúvida que essa grandiosa obra histórica ainda tem por onde nos deleitar e até [nos] instruir. No último caso, porém, o leitor deveria ter sempre em conta este [desconcertante] aviso que eu me lembro de ter lido [eerta vez] à primeira linha de uma gramática russa, e [que] rezava mais ou menos assim: "Antes de mais nada é mister advertir que nesta língua [as regras são as exceções] a regra é a exceção".

Mas [A] a obra de Toynbee [é contude] representa um modelo isolado, e deveras soberbo, feito para [leitores] adeptos mais exigentes do tipo de historiografia a que me venho referindo. O modelo que eu diria tosco, por isso o mais comum, pode ser exemplificado com o episódio de que certa vez fui parte, quando tive de sujeitar-me num programa de rádio a responder a questões - às vezes, como no caso, a autênticos desafios sobre coisas de história, e não só de história do Brasil, que é minha especialidade. O caso foi que uma das perguntas formuladas dizia mais ou menos assim: 
- Quais [foram] são as sete causas da Revolução Francesa?

Isso aconteceu há muitos anos, [ereio que] antes mesmo da era da TV, de modo que já não sei mais como pude quebrar o caroço. É bem provável que não me saísse muito bem, porque Deus me deu um raciocínio tardo e a [inspiração de] improvisação difícil. Mas se, por milagre, me [desse] tivesse dado, na ocasião, alguma presença de espírito, acho que [poderia sair-me com esta] [p. 5] teria respondido:

- Meu querido (ou minha querida) teleouvinte. As causas da Revolução Francesa não [foram] são sete. São setenta e sete. E se eu quisesse ser ainda mais exato, diria [atéł que [foram] são setecentas e setenta e sete. Infelizmente como tenho um prazo muito limitado para as respostas, vejo-me impedido de enunciá-las todas [,dadas as cireunstâneias.].

Seria [essa] esta a forma de me comportar menos desairosamente diante de um ouvinte que devia firmemente acreditar na possibilidade de reduzir todos os sucessos históricos [ao] a um modelo [de] causa-efeito, que parece o mais próprio das ciências físico-matemáticas. Em verdade, se esse modelo [em] a muitos casos poderia aplicar-se, ninguém dirá que é apto a resolver satisfatoriamente todos os intrincados problemas com que $s e$ há de defrontar[-se] o historiador. E mesmo que fosse dado, por hipótese, deslindar precisamente [tode] o emaranhado de causas que se ofereceriam para cada fato [histórice], sempre restaria uma parte - e quem sabe se a mais importante [?] -esquiva a qualquer tentativa de generalização nos moldes das que encontramos em diversas ciências.

Foi sobretudo à vista dessa parte irredutível a leis gerais, e talvez inefável, que se foi firmando entre muitos a ideia de que a história é, por excelência, o domínio do individual e do concreto. Cada sucesso há de ter em si mesmo sua causa e sua explicação. As coisas do tempo são, por sua [própria] natureza, incomparáveis entre si. A história, em suma, não se repete. Essa, em traço grosso, a essência da corrente chamada historista, que se desenvolve, como a outra, sobretudo [na] a partir da era setecentista e tem seu berço principal na Alemanha. Surge com efeito em oposição, muitas vezes oposição deliberada, às tradições jusnaturalistas, que parecem alimentar tanto o racionalismo francês como o empirismo anglo-saxão. Durante todo o século passado, e até muito perto de nós, o historismo, por alguns chamado simplesmente [a] Escola Alemã, chegou a suscitar alguns notáveis monumentos do saber que se sustentam bem até hoje. Tamanho foi o seu prestígio, que desde cedo contaminou os estudos de direito, da filosofia, da economia, da antropologia, [emsuma] de todas as ciências chamadas do Homem.

O problema estava em saber[-se] de que maneira seria possível articular segundo as exigências cada vez mais impositivas da moderna Ciência [moderna], seja ela de caráter empírico, seja de cunho formal, um tipo de conhecimento que se obstina em comprazer-se no individual e no concreto. Atacou-se [ө] esse problema e, também aqui, sobretudo na Alemanha, a partir da noção de que se impunha organizar esse saber verdadeiramente sui-generis, que tem ao centro, e à origem, a História, segundo regras próprias, que a distinguissem dos métodos usados nas demais ciências e, que por muitos aspectos, se [opunham] opusessem a eles. Entre as fórmulas que se alvitraram para estabelecer [essa] $a$ distinção, uma das mais famosas foi a que [eontrapunha] contrapõe às ciências que passariam a chamar-se nomotéticas, outras, a História em primeiro lugar, a que se chamou [p. 6] idiográfica (idiográficas de idios, que significa próprio, particular, individual, e que nada tem a ver com ideográfico). 
Uma vez que o processo histórico é por si mesmo irredutível às leis da causalidade impunha-se alcançar um tipo de conhecimento capaz de apreender o individual por alguma forma de intuição ou de empatia, como se costumava dizer. Na prática esse modo de apreensão pode dar eventualmente resultados plausíveis, dependendo de quem tenha aptidão para dele se valer, e o certo é que qualquer coisa de semelhante foi sempre empregada por artistas de gênio. O difícil [porém] é reduzir a normas transmissíveis aquilo que faz a peculiaridade de indivíduos excepcionais. $E$ [Não] não é talvez por acaso, se a obra onde se deveriam compendiar tais normas, ou seja a Crítica da Razão Histórica de Dilthey ${ }^{20}$, ficou inacabada.

Por outro lado a escola alemã, por mais que $o$ procurassem evitá-lo alguns dos seus adeptos, inclinava-se quase forçosamente à ideia de que o saber prende-se a contingências peculiares a diversas épocas - o Zeitgeist - ou a diferentes povos - o Volksgeist - que acabariam por incompatibilizá-lo com o princípio da universalidade do conhecimento [eientífico] objetivo. Não faltou mesmo quem procurasse associar ao relativismo dogmático e à exaltação do espírito nacional que está implícito nela desde o [seu] nascedouro, a grande catástrofe alemã deI939-I945. Pode-se hoje pensar que tanto a corrente a que, para simplificar, se chamaria de positivista, como ao historicismo, em suas mais variadas formas, tem $o$ seu grau de verdade. O erro estaria em pretender isolar, exacerbar, hipostasiar cada uma delas como se fosse o único método válido de se abordar o passado.

$\mathrm{O}$ [fato da] dito de que a história humana não deve enfocar apenas acontecimentos ou situações únicos e singulares é [sem dúvida in-] discutível. [Mas] $E$ o certo em todo caso é que outro tanto se poderia dizer de muitas ciências teóricas, da geofísica, por exemplo, ou da astronomia, e em geral das que procurem explicar fenômenos concretos. Não é isso um privilégio da História. O mesmo pode-se observar a propósito da pretensão dos partidários da escola idiográfica, de que a apreensão do particular e do concreto só é possível através da empatia ou da intuição. É inegável a existência de um elemento

20 Wilhelm Dilthey (I833-I9II) era a essa altura um velho conhecido de Buarque de Holanda. Quem demonstrou mais detalhadamente uma tal relação de afinidade, mobilizada já em Raízes do Brasil, primeira edição, foi Marcus Vinicius Corrêa Carvalho, que percebeu no livro de 1936 uma dicotomia epistêmica entre explicação e compreensão, que remeteria ao filósofo alemão e seus debates entre ciências da natureza e ciências do espírito - embora não haja referência direta de Buarque de Holanda a Dilthey senão nos anos I950. Antes, para Carvalho, Buarque de Holanda teria conhecido o vitalismo e o historicismo de Dilthey, além é claro durante a convivência com os estudos históricos quando de sua temporada alemã (I929-I93I), através principalmente da leitura de Ortega y Gasset (I883-I955) (Carvalho, 2003, pp. I58-I63). A Biblioteca Sérgio Buarque de Holanda possui as obras Dilthey em edição alemã, doze volumes reunidos entre I959 e I973 sob título geral Gesammelte Schriften. No Brasil, teve duas traduções recentes: Filosofia e educação (Edusp, 2010) e, original de I9Io, A construção do mundo histórico nas ciências humanas (Unesp, 20Io). Dilthey, atualmente, tem sido relido em seus escritos concernentes à biografia como modo de entrada no "mundo histórico". Buarque de Holanda criticamente já percebera em I95I, ao comentar a biografia de Laurita Gabaglia sobre Epitácio Pessoa, o problema da radical separação da história dos métodos das ciências naturais, tal como em Dilthey. Disse, na ocasião, que na prática era muito difícil realizar os preceitos de diltheyanos sobre a biografia como forma ideal de história da história, pois que, tomando o caso em questão, à primeira página do livro a vida se parecia tal qual à última (HOLANDA, [I95I] 20IId). 
irracional e intuitivo em todo pensamento criador, mas esse elemento também aparece no próprio pensamento científico racional. O pensamento racional e analítico não é alheio à intuição. O que o caracteriza é a intuição sujeita a exames e a testes sucessivos, onde por força há de intervir o raciocínio [łógico,]: não é a intuição desvairada e mística. Através da crescente depuração e do aperfeiçoamento das suas técnicas a historiografia pode aspirar, cada vez mais, do estatuto científico. Até a possibilidade de certas generalizações, que em outras épocas passava por heresia, começa a ser estudada e, a esse respeito, são particularmente valiosas as contribuições do Comitê de Análise Histórica do Conselho de Pesquisas [p. 7] de Ciências Sociais dos Estados Unidos, que a imprensa da Universidade de Chicago publicou em I966 sob o título: Generalization in the Writing of History. Admitir essas generalizações é, por outro lado, como admitir o valor que chegam a assumir para o estudioso [que chegam assumir] certas regularidades observadas no curso da História. De onde a importância que vão ultimamente adquirindo as técnicas de quantificação, que supõem por força a presença dessas regularidades, e ajudam a superar o impressionismo irresponsável e a destruir aquele véu de incertezas que tantas vezes prevalece em obras de historiadores.

Em realidade os mais recentes progressos do pensamento científico vão tendendo a dissolver a velha distinção entre o historismo e o positivismo, que espelha tão somente o contraste estabelecido entre o organicismo e o mecanicismo. Isso faz, por sua vez, com que a oposição entre as "leis" das ciências naturais e as chamadas leis da história positivista ou da sociologia positivista, que a rigor procuram copiar o tradicional modelo mecânico de causa e efeito, se [raidissolvende] dissipa cada vez mais.

Já em I926, em seu livro intitulado Leis Naturais e Leis da História, o matemático alemão Karl Groos salientara vivamente esse fato. Sua obra deu lugar a um simpósio realizado em Munique, onde vários físicos, matemáticos, químicos, naturalistas, filósofos e historiadores, manifestaram pontos de vista coincidentes com os seus. Groos apontara, na obra mencionada, para algumas paisagens significativas de escritos de pesquisadores da época, onde se procurava retirar às leis naturais o [eárater de] rigor absoluto que tradicionalmente lhes era atribuído e a reduzir o caráter de certezas indiscutíveis em que eram tidas ao de menor ou maior verossimilhança. Assim, observava um dos debatedores, aquelas leis [são] constituem apenas expressões de dados suscetíveis de serem comparados, e nada mais do que isso. Outro especialista aduziu que as leis da natureza podem, sem dúvida, revestir-se de um caráter estatístico, mas que delas não se podem esperar senão resultados sofrivelmente corretos. Um terceiro afirmou que as leis naturais nada mais exprimem do que [produtos verossímeise] consequências aproximativas de fatores numerosos.

Segundo as [próprias] expressões de Groos, que dera [origem] motivo ao simpósio, na própria Física não se encontram repetições perfeitas, mesmo em igualdade de condições. O que os "positivistas" costumavam chamar "leis naturais" - e que tentavam aplicar, sem bom êxito, à História e à Sociologia - e, fundava-se, não no princípio de identidade, mas tão somente no de similaridade. É outro o fundamento em que se apoiam também os historiadores, todas as vezes em que buscam assentar suas pesquisas em critérios mais plausíveis? De onde a conclusão a que se chegou, ao termo [do simpósio] da reunião de Munique, de que os métodos próprios para as diversas 
ciências, chamem-se elas, embora, Ciências do Espírito ou Ciências [p. 8] da Natureza não apresentam, entre si, nenhuma diferença verdadeiramente essencial.

Ora, a ideia que ainda poderia passar por audaciosa em I926, entrou decididamente na ordem do dia durante estes últimos 20 anos. A experiência adquirida através do desenvolvimento das ciências, e que se reflete nas ideias centrais da Cibernética, revelam como os antigos esquemas, que procuravam enquadrar a realidade, ora segundo o símile das máquinas, ora à imagem dos organismos vivos, já perderam sua razão de ser. O mecanicismo busca abranger o real segundo os rígidos critérios de causa e efeito, e medir o tempo [por um] com a precisão de um relógio, essa primeira máquina do mundo moderno e, em verdade, o primeiro autômato. Ao contrário dos moinhos, por exemplo, que dependem, para seu funcionamento, de forças naturais como a água corrente ou os ventos. Mas os relógios mais antigos pouco tinham a ver com os da atualidade, que só se prenunciam, por assim dizer, em fins do século XV. Além disso, a sua utilidade quase única nos conventos, onde primeiramente se tinham usado, consistia em assinalar as horas canônicas e, para os sacristães medievais, eram pouco mais prestativos do que os cães de guarda. Para outros usos serviam, de ordinário, os relógios de sol, ou as clepsidras, ou as ampulhetas, que não marcam os minutos, muito menos os segundos, e parecem obedecer antes a um ritmo natural do que a um compasso mecânico.

Mas mesmo depois da invenção, por volta de I500, do relógio de bolso, atribuída a um certo Peter Heinlein, de Nuremberg, foi preciso esperar longo tempo até que seu emprego se generalizasse e se impusesse a todos. Os relógios medievais tinham servido para lembrar as horas de devoção e de festividades. Os novos, que de início não passavam de simples objeto de curiosidade, teriam seu emprego primeiramente, no estímulo que, por intermédio de seu mecanismo, dariam à indústria de brinquedos infantis de mola, em que se celebrizaria a cidade de Nuremberg, conhecida até aos nossos dias, como terra desses brinquedos. Só muito mais tarde se converteriam eles em instrumentos para a medição do tempo, tornando-se os responsáveis pela nossa civilização do relógio, civilização de homens que não [querem] gostam de perder tempo. O relógio "fabrica o tempo", segundo a expressão inglesa. Ele nos impôs o tempo mecânico, o tempo abstrato, que parece regular amplos setores de nossa humanidade atual e que nos parece tão diferente do tempo da História, [que resiste] refratário, tanto quanto pode ser, a esse regulamento. E é o relógio que [nos] forneceu o modelo clássico do "mecanismo": modelo que, no sistema de Newton, se aplicou à descrição dos astros; ao do governo nos escritos de Maquiavel e Hobbes, o teórico do Estado Leviatã; às teorias da "balança do poder" e do equilíbrio mútuo - "check and balance" em Locke, Montesquieu, e os autores da Constituição dos Estados Unidos; [p. 9] mesmo ao corpo humano, nas doutrinas de La Mettrie. E não faltou, na era das Luzes, quem se valesse do símile, para referir-se a Deus Todo-Poderoso, que, para Voltaire, é o "primeiro relojoeiro", e para o cidadão Tomas Paine, o "primeiro mecânico", enquanto os pedreiros livres chamavam-no o "grande arquiteto".

Foi contra os excessos e, ao cabo, contra as insuficiências desse modelo [meeanicista] mecânico, onde o relógio de molas aparece como a expressão mais simples, que se engendrou o modelo organicista. Muito mais do que a máquina, criatura humana, por conseguinte imperfeita, os seres vivos, que são obra divina, iriam dar agora o ponto de partida mais adequado para a boa inteligência das coisas deste mundo. E se o 
primeiro encontra sua mais autêntica expressão nas doutrinas positivistas, o segundo irá melhor manifestar-se por intermédio do pensamento historista. O mecanicismo contribuíra, dentro dos seus limites naturais, para tornar possível um tratamento rigoroso e quantitativo de todos os fenômenos, mas, de outro lado, era incapaz de representar perfeitamente os processos de crescimento e a evolução. Por outro lado, os modelos tomados aos organismos vivos, segundo a concepção clássica, pareciam em parte atender a tais exigências, dando maior complexidade e generosidade ao tratamento de [eertos] vários aspectos da realidade. No entanto, deixavam margem escassa [para] à consciência e à vontade, [que pareciam] aparentemente impróprias para alterar as leis que regem internamente os seres vivos. Deficiências semelhantes resultam do modelo, parcialmente inspirado na mesma concepção organicista, em que se procura refletir o processo histórico. Estes, embora possam propiciar modificações qualitativas, assim como a influência da ação consciente e [à] a inovação genuína, permanecem estreitamente na esfera qualitativa e, se ajudam no reconhecimento de certos padrões de comportamento, mostram [-sede] escasso préstimo onde quer que importe contar ou medir ${ }^{2 \mathrm{I}}$.

Impunha-se, pois, a conclusão de que muitos desses esquemas, não só deixam de atender hoje às novas exigências mentais, como não espelham fielmente próprios modelos originários, sustentando-se só pela [sic] [rotina] uso continuado. Para citar um exemplo, a ideia clássica da máquina, implicando a noção de um todo sempre igual à soma das partes, isolado [de seu] do meio, inalterável através do tempo ou da interação [de suas] das partes, infenso à mudança irreversível, ao crescimento, à evolução, à novidade, já não [se acomoda à] condiz com a complexidade dos mecanismos atuais. E não só isso: a própria fissura newtoniana e, depois, a termodinâmica clássica, só imperfeitamente se deixam abordar através desse tipo de máquina, cujo modelo ideal é concebido [segundoas] à maneira das rodas e molas de um relógio. Tornou-se necessário chegar até aos nossos dias para [ehegar-se] assistirmos ao colapso dessas noções singelas, devido à impossibilidade, entre outras, de se abordar por seu intermédio o que [se passa] ocorre no interior do átomo, que passou a reclamar novas teorias físicas como a da relatividade e a do [p. Io] quantum. Parece inevitável que essas concepções novas, por onde se busca enfocar com maior precisão uma realidade dinâmica, e resistente a quaisquer critérios fixos e imutáveis,

2I Se aqui notamos algumas reservas de Buarque de Holanda quanto ao organicismo, ainda que mais simpático a este que ao mecanicismo e ao positivismo, vistos como espécie de raízes filosóficas da sociologia científica e do estruturalismo, enquanto o organicismo ele ligava ao historicismo, essas reservas têm um ponto de partida mais ou menos claro a partir da segunda edição de Raízes do Brasil, em I948, como bem notou João Kennedy Eugênio. Ele é autor de minucioso cotejo das edições primeira e segunda e de densa análise das matrizes intelectuais do clássico ensaio, que para Eugênio se alterna entre organicismo e sociologismo - em um contraponto ou equilíbrio de antagonismos que marcam a própria modernidade -, por sua vez refletidos em matrizes rivais da fortuna crítica de Raízes do Brasil, identitária (cuja referência é M. Odila Dias) e sociológica (inaugurada com o prefácio de A. Candido para a quinta edição de Raízes do Brasil). Conforme Eugênio, Buarque de Holanda atenuaria o organicismo de Raízes do Brasil em I948, embora não se lhe desfizesse, até por se tratar do âmago mesmo do ensaio, que, tal qual um organismo, é adaptável e se modifica desde dentro: "Sérgio Buarque buscou apagar as marcas das leituras alemãs menos palatáveis ao ideário progressista que passou a abraçar" (EUGÊNIO, 20II, p. 38). 
venham a deixar sua marca, e cada vez mais, no desenvolvimento dos estudos históricos. O próprio recurso aos dados estatísticos (e não apenas ao princípio qualitativo) como meio de verificação dos sucessos abordados pelo historiador, poderá adquirir uma dimensão nova à luz de tais concepções. Já se tem notado como a quantificação [já] aparece [emeşe] implícita na historiografia tradicional, todas as vezes em que se usam termos tais como "típico", "representativa”, "significativo", "generalizado", "crescente”, "intenso”. Todos eles envolvem sem dúvida afirmações quantitativas, embora não se apresentem cifras em que possam apoiar-se essas afirmações. Desde há algum tempo, e primeiramente, segundo parece, nos países anglo-saxões, os historiadores vêm procurando utilizar-se de tais métodos para dar fundamento mais plausível às suas descrições, e a tendência se acentuou principalmente no campo da história econômica, onde é mais fácil a quantificação, já que os dados, em geral, aparecem aqui naturalmente, em forma quantificada. Hoje alguns adeptos da história quantitativa já se lançam às estatísticas a todo propósito, com um ardor de neófitos que chegaria a fazer inveja aos adeptos das tendências positivistas, passando a desdenhar todos os outros recursos possíveis, sem perceber que [elas] aquelas têm um alcance limitado e, ainda, que a imensa maioria das questões suscitadas pelo estudo do passado e do presente dificilmente se deixam resolver através de números.

Mesmo no Brasil a quantificação principia a expandir-se de tal sorte que, para muitos, a presença de números, tabelas ou gráficos já parece indispensável em qualquer trabalho histórico digno desse nome. O êxito e o alcance de algumas obras notáveis, tais como o livro clássico de Earl Hamilton sobre a revolução dos preços na Espanha, publicado em I934, mas principalmente com o Seville et I'Atlantique de Pierre e Huguette Chaunu ${ }^{22}$, que em oito dos seus doze e às vezes compactos volumes, quase só apresentam cifras, são os principais responsáveis por essa moda. E embora as insuficiências [desse] do recurso sejam [bastante] óbvias, impõem-se, além disso, cautelas especiais, principalmente quando se sabe que a ausência de rigor nos dados numéricos foi no Brasil e em parte continua a ser ainda hoje, regra geral.

A precisão numérica, que se tem acentuado particularmente em terras onde se implantou a civilização industrial, é com frequência alheia a outras eras e a outros povos. "Os números”, escreveu ultimamente o historiador norte-americano John U. Nef, "ocupam em nosso vocabulário uma importância que nunca, até aqui, tinham chegado

22 Pierre Chaunu (1923-2009), agrégé em história e docteur ès lettres, professor na Université de Caen (I962), depois na Paris-IV Sorbonne (I970), é o principal avatar da chamada história serial ou quantitativa, nomenclatura por ele mesmo proposta para uma história econômica e social, próxima à demografia e à geografia, que se serve principalmente de dados estatísticos. Seville et l'Atlantique foi publicado pela VI seção da École Pratique des Hautes Études entre I955 e I960, em oito tomos, dos quais os sete primeiros compõem a "primeira parte, estatística", e o oitavo e último, em dois volumes, a "segunda parte, interpretativa”. Em uma resenha de 1963 sobre Seville et l'Atlantique, Braudel procurou demarcar algumas diferenças entre seus trabalhos e os de Chaunu, ainda que reconhecesse grandes méritos neste. A principal delas, enquanto Braudel dizia ter intentado uma história global, das imobilidades aos movimentos dos homens, Chaunu, em sua visão, limitava-se a uma história de corte exclusivamente econômico (BRAUDEL, I963). 
a ter”. E Lucien Febvre ${ }^{23}$, em páginas justamente célebres sobre o problema da descrença no século XVI, relaciona tal fato com [p. II] a carência de senso histórico, imperante não só [durante a] entre os homens da Idade Média como em pleno Renascimento, e que levara muitas vezes à absorção da história pelo mito."Nesse passado indistinto”, diz, "que se resumia em palavras tais como antigamente, sem maior rigor, ou como outrora, e ainda há muito, quantos não continuam a admitir, sem cerimônias excessivas, a presença de personagens míticos, lado a lado com figuras históricas, algumas mitificadas, se assim se pode dizer, uma espécie de promiscuidade fluida, que hoje nos escandaliza e àquele tempo não perturbava ninguém”.

Dissentem atualmente os eruditos sobre o ano exato em que teria [naseide] vindo ao mundo, por exemplo, Lutero. Quanto a Rabelais, dividiam-se os velhos textos, relativamente à era de seu nascimento, entre os anos de I483, I490 e I495. E tudo leva a acreditar que muitos dos homens ilustres do século XVI, desse século que ainda não se deixara contaminar pela revolução do relógio, e também do calendário, sabiam muito menos a própria idade do que o sabem os seus biógrafos de hoje. É que a exatidão cronológica deveria parecer-lhes coisa supérflua e indiferente. Quando muito valiam-se, em certos casos, de vagas cifras que não pretendiam espelhar com nitidez os fatos reais. Numa época ainda [mal] pouco afeita aos cálculos matemáticos, e em que os próprios algarismos árabes mal começavam a desalojar os números romanos, que são inadequados para a realização de muitos daqueles cálculos, não se necessitava de muito mais.

23 Buarque de Holanda refere-se a Le problème de l'incroyance au XVI' siècle: la religion de Rabelais, livro de I942 de Lucien Febvre (I878-I956), professor desde I933 no Collège de France e fundador, em I929, ao lado de Marc Bloch, dos Annales d'histoire économique et sociale. A Revista de História é inaugurada em I950 com o texto de uma conferência de Lucien Febvre pronunciada na FFCL, em setembro de I949, justo sobre "O homem do século XVI”, que remete à obra em questão. Febvre faz reflexões sobre o homem, em sua totalidade, inclusa sua bagagem mental, como objeto da história: "o homem que age, aflito, sofrendo e trabalhando, [...] dotando-se, mental e sentimentalmente de um futuro humano que possa projetar para além de si mesmo e que o leve a libertar-se de seus humildes princípios” (FEBVRE, I950, p. 7). Nessa viagem ao Brasil em I949 Febvre esteve com Buarque de Holanda, além de Eurípedes Simões de Paula, Octavio Tarquínio de Souza, Gilberto Freyre e outros - segundo consta no carnet de voyage do historiador, localizado no acervo pessoal de Febvre na École des Hautes Études en Sciences Sociales - EHESS (FEBVRE, I949). Buarque de Holanda e Febvre já haviam participado em I948 de enquetes promovidas pela Unesco sobre diálogos interculturais quando Buarque de Holanda comentou Febvre na imprensa. Em "Para uma nova história”, Buarque de Holanda mobilizava o célebre artigo de Febvre "Vers une autre histoire" (I949), contra "os que, ainda em nossos dias, se apegam teimosamente ao preceito positivista do fato puro" (HOLANDA, [I950] 20IIc, p. 23). Alguns anos depois, ambos estariam à mesma mesa em Genebra para um debate, também promovido pela Unesco, entre o Novo Mundo e a Europa. Buarque de Holanda apresentou "Le Brésil dans la vie américaine", e Lucien Febvre, "Les lumières de Clio" (FEBVRE, I955). Merece menção, ainda, e talvez principalmente, a afinidade temática relativa ao universo mental do século XVI entre Febvre e Buarque de Holanda em Visão do Paraíso. Entre eles, como fez notar Thiago Nicodemo, a importante presença mediadora do historiador econômico da Sorbonne, também especialista no século XVI, Henri Hauser (I866-I946), integrante do comitê de redação dos Annales em I929 e professor na Universidade do Distrito Federal em I936-I937, de quem Buarque de Holanda foi assistente junto à cadeira de História Moderna e Contemporânea (NICODEMO, 2008, p. I50). 
Ora, o que era verdadeiro entre os europeus do século XVI é largamente válido, aqui no Brasil, mesmo para épocas muito posteriores e, muitas vezes, até bem entrado o século XIX. Para lembrar um exemplo [que me é familiar], direi que, no Arquivo do Estado de S. Paulo, que conheço melhor do que outros, se guardam ainda hoje muitíssimos maços de população que, desde I766, e até muito depois da Independência, se faziam na Capitania [p. I2], depois Província, principalmente para o efeito de recrutarem-se homens destinados às lutas contra os castelhanos no sul, onde as somas relativas à população, aos gêneros consumidos ou exportados, os escravos e serviçais estão quase por sistema errados. Essa documentação, não obstante, é hoje preciosa para o conhecimento de muitos aspetos de nosso passado, mas é indispensável utilizá-la com espírito crítico e cautela, pois não se espere delas o rigor que estamos habituados hoje a assimilar às cifras numéricas.

Por estranho que pareça, a produção de ouro, que foi a grande riqueza do Brasil durante o século XVIII sujeita-se ainda hoje a controvérsias e não há por ora meio seguro, mesmo excluído o contrabando, naturalmente incalculável, de se alcançarem[-se] a respeito dados mais exatos. O mesmo é possível dizer a respeito do açúcar, durante a era colonial e em parte o último século. Isso porque os dados em geral registram as quantidades em caixas, e essas caixas se faziam [- da] conforme a madeira disponível, e tinham dimensões forçosamente variadas. No caso dos escravos importados, complica-se a situação porque a unidade geralmente registrada é a "peça", e a peça não é senão em certos casos sinônimo de escravo. No uso ordinário equivalia a 7 quartas de vara, isto é, entre I,75 e I,82 metros, aparentando o preto ter entre 30 e 35 anos. Usualmente 2 negros de 35 até 40 anos correspondiam a uma peça, mas 3 molecões entre 6 e I8 anos formavam 2 peças.

Até no caso do café podem suscitar-se incertezas. Mas estatísticas, por exemplo, relativas à sua produção durante o século passado, conhecem-se ao menos quatro tabelas estatísticas diferentes umas das outras. A razão dessas divergências está em parte no fato de algumas dessas estatísticas trazerem [quase-sempre] o número das sacas, que nem sempre eram de 4 arrobas, isto é de 60 quilos. Até I873 predominavam, embora não exclusivamente, as de 5 arrobas, quer dizer de 75 quilos. Muitas vezes não se consideram essas discrepâncias, ou não há como distingui-las, e computando-se sempre sobre a base hoje usual de quatro arrobas, e arrobas métricas, chega-se a resultados diversos.

Nada impede que se usem as cifras disponíveis sempre que não nos seja dado chegar a um rigor absoluto. Elas hão de valer, quando menos, para se chegar a dados aproximativos. O que importa é considerá-las pelo que possam valer sem querer atribuirlhes um significado que, em muitos casos [elas] não nos podem proporcionar.

É esse caráter fragmentário ou impreciso da documentação que dispomos sobre o passado, que dificulta a sua manipulação para fins de estudos, [sem falar na] além da natural complexidade da matéria, um dos obstáculos mais frequentes que encontra o historiador. Sabemos, no entanto, que as mesmas dificuldades existem, em maior ou menor grau para as próprias ciências naturais.

[Ө] Mas o obstáculo maior para chegar-se a uma história verdadeiramente científica não está apenas nisso. Está em que a História, para os homens não representa tão só um objeto de contemplação desinteressada e um espetáculo. [p. I3] Em verdade nós vivemos a História e a ela pertencemos de corpo e de alma. Tanto que se faz mister às vezes 
uma devoção quase heroica para nos desvincularmos dessa condição e, por conseguinte dos mitos e tabus que podem embaçar nossa visão da realidade histórica. Pode-se resumir dizendo que um desses vieses perturbadores se associa ao nosso tribalismo, e o outro ao nosso tradicionalismo. São essas sem dúvida, mais do que quaisquer outras, as barreiras que embaraçam o tratamento objetivo do passado.

A história tribalista é a que impõe como obrigação sacrossanta construir o passado nacional sob a forma de uma imagem sem jaça. Admite-se, com frequência, que o presente possa ser alvo de acerbas críticas e imprecações. Raros são, porém, os que toleram qualquer tentativa de ver nesses erros do presente um fruto dos erros do passado que os pudessem servir para [explieá-łos] explicar e porventura para superar. O passado nacional há de apresentar-se como uma procissão de imaculadas glórias, e [dizer] querer outra coisa é cometer pecado de leso-patriotismo. Ora, o patriotismo verdadeiro é feito de lucidez, não é insurgir-se contra ele, ou tentar feri-lo, o pretender que não há, não [pode] deve haver uma história patriótica, como certamente não há matemática ou biologia patrióticas.

Intimamente vinculado a esse tribalismo acha-se a ideia generalizada de que o historiador é, por força, um indivíduo que só há de ter olhos para o passado, nacional ou não, e que sua missão essencial é zelar pela preservação de tudo quanto foi imunizado e de certo modo canonizado pela pátina do tempo. A esse propósito me parece sempre oportuno o caso narrado por Marc Bloch ${ }^{24}$ acerca do grande historiador belga Henri Pirenne. Chegado certa vez a Estocolmo para um Congresso de historiadores, o autor de Mahomet e Charlemagne surpreendeu alguns dos seus companheiros dizendo que para ver a cidade iria começar pelo edifício da Municipalidade, que era um prédio moderníssimo. E como se quisesse

24 Em julho de I950, uma semana antes do texto citado em nota anterior sobre Febvre, Buarque de Holanda publicara, na Folha da Manhã (SP), um ensaio intitulado “Apologia da história”. Nele, afirmava que a reabilitação dos estudos históricos passaria, proveitosamente, pela atenção dedicada aos problemas de historiografia. Em alusão ao inacabado Apologie pour l'histoire ou métier d'historien (publicado postumamente em I949), do cofundador dos Annales, Marc Bloch (I886-I994), professor em Strasbourg (I9I9), depois na Sorbonne (I936), Buarque de Holanda asseverava que "para o verdadeiro historiador" importava, antes de tudo, “o esforço para a boa inteligência da hora presente, se quiser entender o passado". Exemplos próximos dessa reabilitação, voltada aos problemas postos pelo tempo presente, seriam a publicação recente da Teoria da história do Brasil (I949), de seu ex-assistente anos antes no Instituto Nacional do Livro, José Honório Rodrigues (I9I3-I987), e a fundação da Revista de História pelo professor Eurípedes Simões de Paula, em I950. Ambas as publicações mostravam “o verdadeiro sentido de uma disciplina [...] vital para a época presente” (HOLANDA, [I950] 20Irb, p. I8-2I). 
prevenir o espanto dos presentes, ajuntou: "Se eu fosse um antiquário só me interessariam as velharias. Mas [eu] sou historiador. Por isso [eu] amo a vida”25.

$\mathrm{O}$ culto ao passado, como passado, está em verdade no polo oposto às preocupações do verdadeiro historiador. Para começar, a própria palavra "passado", posta assim no singular, não passa de uma abstração. Há o passado de ontem, [1𤣩 de julhø] 28 de agosto e há o de há cem anos ou os passados de antes da era cristã. Entre eles, não há medida comum, e nesse sentido é que se devem entender as palavras sábias de Goethe, onde dizia que "a verdadeira missão da história consiste em libertar-nos do passado".

[A primeira condição para se chegar à melhor inteligêneia da História está em procurar eompreender o presente. Muitos exageros já se tem eserito sobre a missão a lieção da História, que os antigos]

[p. I4] De vícios tais acham-se contaminados, até os dias de hoje, largos setores de nossa historiografia. Para citar um exemplo bem conhecido lembrarei as controvérsias ainda correntes em torno da [eausalidade] casualidade ou intencionalidade do achamento da terra do Brasil. A hipótese tradicional de que o Brasil não tinha sido descoberto por acaso combatida no século passado por um autor que, segundo confissão por ele

25 Essa anedota, envolvendo o medievalista Henri Pirenne (I862-I935), narrada por Marc Bloch na Apologie, foi desde então muito frequentemente mencionada por Buarque de Holanda para ilustrar sua concepção de história - e de algum mudo inscrever-se nessa linhagem. No artigo "Apologia da história”, de I950, Buarque de Holanda convocava Bloch, "um dos mais ilustres historiadores de nossos dias", em sentido de complementaridade a uma máxima de Goethe, também muito recorrente em Buarque de Holanda, sobre a história como exorcismo e libertação do passado. "História é movimento e mudança”, ele não cessará de repetir. A partir da leitura de Marc Bloch, contudo, Buarque de Holanda dinamiza a compreensão histórica, considerando as circulações entre passado e presente, a ciência e a vida, mediadas pelo problema histórico. A dimensão compreensiva da história é compartilhada, entre outros, por Max Weber e pelo próprio Marc Bloch, este último já visto como, no período entre as duas guerras, o principal mediador entre a ciência histórica alemã e a história à francesa. Lemos, em Marc Bloch, que além do tempo presente como lugar de inteligibilidade da história, esta não tinha razão de ser senão para ajudar a viver melhor. Conforme o exemplar consultado na Biblioteca Sérgio Buarque de Holanda, setor de Coleções Especiais e Obras Raras da Biblioteca Central Cesar Lattes (CEOR/BCCL) da Unicamp: “Un mot, pour tout dire, domine et illumine nos études: 'comprendre"' (BLOCH, I949, p. 72) - "uma palavra, para resumir, domina e ilumina nossos estudos: 'compreender", na tradução brasileira (BLOCH, 200I, p. I28). 
feita mais tarde a Capistrano de $\mathrm{Abreu}^{26}$, quisera tão somente levantar problemas, converteu-se aos poucos em dogma, pois parecia melhor coadunar-se com a ideia de que os heróis da era dos descobrimentos, eram homens tão superiores que seria fazer-lhes injustiça supô-los capazes de fazer qualquer coisa sem propósito definido e maduramente pensado. Um dos argumentos mais significativos em prol da tese do intencionalismo, surgira muito antes, aliás, diante do testamento de João Ramalho, onde o patriarca de Piratininga teria dito em I580 que contava, então, "alguns noventa anos de [idade] assistência” nessa terra. Se interpretado literalmente, esse documento permitiria atribuir a Ramalho uma longevidade incomum e arrebataria mesmo a Colombo a primazia no descobrimento da América. O testamento, que foi lido e comentado em fins do século XVIII por Frei Gaspar da Madre de Deus acha-se hoje desaparecido. Contudo conhece-se uma Ata da Gamara da Vila de S. Paulo, datada de I564, onde o mesmo Ramalho, dirigindo-se aos vereadores da mesma vila, se diz homem velho, passante dos setenta anos, e isso faz pensar que não contaria então mais de 75 anos. Como era casado e veio ao Brasil sem a mulher, ainda se reduz assim mesmo, de modo considerável, o tempo em que poderia ter estado entre nós. Apesar disso, os adeptos dos mesmos critérios não deixaram, recentemente, de socorrer-se de argumentos de mesmo teor e aparentemente de igual valor.

Entre os mais lembrados figura o caso da carta que em I5I4 endereçou a El-Rei de Portugal, Estevão Fróis, preso então nas Antilhas pelos castelhanos, sob a acusação de ter violado terras estranhas à demarcação lusitana convencionada em Tordesilhas. No interrogatório a que foram sujeitos, Fróis e seus companheiros declararam que vinham de lugar situado I50 léguas ao sul da linha equinocial, pertencente à Coroa portuguesa “Há vinte anos e mais...”. Entendido ao pé da letra, isso quereria dizer que já viveriam portugueses no Brasil por volta de 1493 ou antes. Outro tanto há de cuidar quem interprete literalmente os depoimentos de marinheiros lusitanos ante o tribunal de Baiona, que julgava a apreensão por portugueses da nau La Pélerine, cujos tripulantes tinham feito depredações em Pernambuco no ano de I532. Alegavam as testemunhas que no mesmo porto de Pernambuco estava "um castello e fortaleza feyta por El Rey nosso Sôr e seus

26 Embora a ligeira e discreta menção a Capistrano de Abreu, o historiador cearense teve papel destacado na formação da concepção de história em Buarque de Holanda, que inclusive mencionou tê-lo conhecido pessoalmente, por intermédio de Paulo Prado (I869-I943), discípulo declarado de Capistrano (HOLANDA, 2009c, p. I90). Em I95I, em um balanço da historiografia brasileira da primeira metade do século XX, o historiador paulista entronizou Capistrano como fundador da moderna historiografia brasileira, bem como forçou uma inusitada aproximação entre as concepções e práticas historiográficas deste e de Marc Bloch, como se Capistrano intuísse e até antecipasse aquilo que seria preconizado pelos Annales. Apesar de certa relação com o comtismo e o spencerismo, Capistrano, na visão de Buarque de Holanda, estava mais distante de uma história dita positivista. A sua prática de divulgação e crítica de documentos contribuiu para novos desenvolvimentos, por aqui, da história social e econômica, além do olhar devotado ao interior do país: "Ele [Capistrano de Abreu] sabia, no entanto, que esses documentos só falam verdadeiramente aos que ousam formular-lhes perguntas precisas e bem pensadas. Sabia, em outras palavras, palavras de um grande mestre moderno - Marc Bloch -, que toda pesquisa histórica supõe, desde os passos iniciais, que o inquérito tenha uma direção definida” (HOLANDA, [I95I] 2008a, p. 602). 
vasalos, a qual avya trinta anos e mais que no dito porto era feyta, e era o dito porto e castello habitado pelos portugueses que tinham ay suas moradas [p. I5] avya quarenta anos e mais...”.

Com razão já ponderou Duarte Leite, antes mesmo de publicadas as observações de Lucien Febvre acerca da imprecisão numérica generalizada no Quinhentos, o pouco crédito que hão de merecer dados semelhantes, lembrando como as expressões "avya trinta anos e mais" e "avya quarenta anos e mais", outra coisa não são do que um modo de recuar o fato narrado a época longínqua e indeterminada. Acresce que, sendo as testemunhas portuguesas, teriam todo empenho em mostrar a antiguidade, por conseguinte a legitimidade, da posse da terra pelo seu soberano. A ninguém ocorreria discutir a exatidão rigorosa das cifras alegadas, como ninguém, em I580 iria objetar contra as declarações de João Ramalho, o qual segundo Frei Gaspar, "duas vezes repetiu que tinha alguns noventa anos de assistência nesta terra sem que alguns dos circunstantes lhe advertisse que se enganava”, apesar de em outra ocasião e com propósito diferente ter apresentado cifras bem diversas. Essas observações não se dirigem contra a tese do intencionalismo que todavia, apesar do fervor dos seus adeptos, ainda está para ser demonstrada, mas apenas para salientar os riscos em que podem incorrer os que, na abordagem dos sucessos históricos, se deixam inspirar cegamente pelas suas inclinações nacionalistas. Ainda mais tosca, e aparentemente animada por motivos políticos, é a teoria recentemente formulada, de que o Brasil nunca chegou a ser colônia, e que tal ideia só começou a aparecer no século XIX, graças largamente à História do Brasil de Robert Southey ${ }^{27}$. Estimulados aparentemente, em sua convicção, pelo panfleto que publicou em I95I o historiador argentino Ricardo Levene, sob o título "Las Índias no eran Colonias", essa tese ganha reforço com o fato de dar uma longa genealogia aos princípios sustentados em Portugal pelo Professor Antonio de Oliveira Salazar, de que seu país não tem colônias, mas províncias ultramarinas.

27 O inglês Robert Southey (I774-I843), poeta e historiador romântico, era objeto de estudo de Maria Odila Dias. A então assistente da cátedra de História da Civilização Brasileira defendera, em I965, título de mestre, sob a direção de Buarque de Holanda, com "O Brasil na historiografia romântica inglesa”. Alguns anos depois, I972, com orientação de Maria Thereza Petrone, outra ex-orientanda de Buarque de Holanda, Odila Dias defendia tese de doutoramento intitulada "Robert Southey, historiador do Brasil: o fardo do homem branco na Inglaterra Pré-Vitoriana e a formação da nacionalidade brasileira”. A tese saía em livro em I974, sob título O fardo do homem branco: Southey, historiador do Brasil, pela Companhia Editora Nacional, com prefácio de Buarque de Holanda. Nos anos I970, aposentado, Buarque de Holanda marcou presença em diversos prefácios aos livros de ex-estudantes seus - sinal de grande prestígio e afirmação da autoridade intelectual. Invariavelmente, nesses prefácios, tratou de sua incidência sobre o feitio dos trabalhos agora publicados em livro. No trecho a seguir, uma reflexão, além disso, sobre os cuidados devidos na prática da história da história: "Maria Odila da Silva Dias, a autora deste livro, não se filia aos devotos do historiador poeta ou, ao menos, não pretende apontá-lo como um modelo sempre vivo. Julgo conhecê-la bastante como antiga aluna e, mais tarde, assistente da cadeira de história da civilização brasileira na faculdade de Filosofia, Ciências e Letras da Universidade de São Paulo, então sob minha responsabilidade, para saber que, com sua curiosidade intelectual constantemente alerta, [...] tem todo o necessário para distinguir os caminhos e os descaminhos que podem levar às restaurações postiças e fraudulentas" (HOLANDA, [I974] I996b, p. I60). 
O principal argumento dos que sustentam semelhante tese é o de que em nenhum dos documentos da nossa época chamada colonial, aparece a expressão aborrecida. Poderia lembrar-se que já em I794 isto é muito antes de Southey e da Independência, o bispo José Joaquim da Cunha de Azeredo Coutinho publicava em Lisboa e sob os auspícios da Academia Real de Ciências, o seu trabalho intitulado Ensaio Econômico sobre o comércio de Portugal e suas Colônias. E se muito antes disso não se acha a palavra "colônia" nos textos relativos ao Brasil é, muito provavelmente porque essa palavra não tinha então o significado que hoje lhe damos e que só aos poucos iria adquirir. O termo se empregava mais correntemente para designar as colônias militares e conforma-se nessa acepção ao sentido que lhe davam os romanos. Isso explica como uma área fortificada e ilhada entre desertos e castelhanos [teve] recebe o nome de Colônia, desde I680 - a Colônia do Sacramento - enquanto ao Brasil, só muito mais tarde se começou a dar essa designação. [p. I6] Mesmo a palavra colono só começará a empregar-se tardiamente: em lugar dela costumava-se dizer, de preferência, povoador, que tanto servia para designar o fundador de uma povoação como seu habitador.

Dizer que o Brasil não foi colônia só porque não se conhecia então a palavra, é como quem pretendesse, por exemplo que Portugal, por conseguinte o Brasil, nunca teve monarcas absolutos, por isso que a expressão absolutismo, seja qual for o sentido que lhe deem, era de todo desconhecida naquelas eras. O próprio dicionário de Morais ainda não registra a palavra em sua primeira edição que é de I8I3. Mesmo o verbete absoluto tem nele apenas os significados de "independente", "livre” e só depois, mas por derivação lógica de tais acepções, "com pleno senhorio, poderoso", "que não tem dependência, respeito, relação com outra coisa”. Na exemplificação aparece "Homem absoluto” para designar livre ou independente. A expressão poder absoluto poderia eventualmente ser indicada para indicar [sic] que esse tal poder é independente de qualquer sujeição, e não que rege absolutamente os povos.

E provável mesmo que com o sentido atual a expressão governo absoluto irá surgir por contraste com liberal. Mas esta própria palavra liberal só se encontra em Morais para designar "o que é largo no dar e despender, sem avareza e nem mesquinharia, dadivoso”. Encontra-se também com o sentido de livre e franco, mas nesses casos com sentido que transparece da exemplificação dada, proveniente, ao que parece, de João de Barros, a saber: "tanto que por nós lhe foi impedida esta liberal navegação". Aparece a fórmula arte liberal, ou seja expressamente aquela "que não é mecânica”, e também liberaleza, liberalidade, liberalmente, mas sempre como extensão do significado atribuído pelo dicionarista a liberal. O que não aparece decididamente é liberalismo.

Se o critério da existência ou não, de determinados vocábulos servisse para determinar, ou não a presença, nesta ou naquela era, da coisa significada, seria forçoso concluir-se que o imperialismo, por exemplo, foi desconhecido durante a maior parte do século passado. A palavra existia, é certo, mesmo e particularmente no Brasil e pode ser achada em quase todas as páginas do célebre panfleto de Tito Franco de Almeida impresso em I867, célebre sobretudo pelas notas que D. Pedro II rabiscou às margens de seu exemplar e que hoje se acham 
publicadas. Existia, no entanto, para indicar simplesmente o chamado "poder pessoal” do imperante, assim como "imperialista” era o partidário desse poder. No panfleto citado diz-se, por exemplo: "O prestimoso chefe do primeiro gabinete imperialista (o autor queria referir-se aqui ao Marquês do Paraná, que com seu governo da Conciliação teria obedecido a um pensamento augusto), que por dolorosa expiação de Io anos havia aprendido a descobrir e apreciar o poder do Imperialismo, curvou-se também, etc.”. E D. Pedro escreveu pressuroso à margem: “O Paraná não se curvava”.

[p. I7] Com seu significado hoje mais generalizado, essa palavra "imperialismo" é cunhada na Inglaterra mais de dez anos depois. Um especialista nestes assuntos, o sociólogo e historiador George Hallgarten, que deixou dois exaustivos volumes ao tema do "imperialismo antes de I9I4", localizou-a pela primeira vez; em artigo de Lord Carnavon publicado a I de dezembro de I878 na Fortnightly Review, onde se lê: "Temos ouvido falar até aqui, é certo em interesses imperiais, em política imperial, só é novo o conceito que se exprime nesta palavra nova: imperialismo”. Esses exemplos e esses vocábulos, que poderiam ser multiplicados, ajudam-nos a mostrar como cada época da história tem as suas peculiaridades distintas, que não se deixam impunemente transferir às outras. O que Leopold von Ranke assinalou em seu dito célebre: “Cada época se relaciona imediatamente a Deus". Se assim como não nos é lícito refazer os tempos idos ao sabor de nossos caprichos e paixões de hoje, também não podemos entender ou explicarmo-nos o presente se o sujeitarmos à imagem de um passado idealizado e, naturalmente, deformado pela 
imaginação ${ }^{28}$. Se há uma lição da História, que os antigos chamaram "mestra da vida" é esta sem dúvida. O que nos compete a nós, estudiosos e estudantes de História é, antes de tudo procurar viver o nosso tempo, sentir as suas pulsações, pressentir, se possível, os seus rumos e, se preciso, nos acumpliciarmos com suas aspirações, ainda que nos exponham ao risco de passarmos por inconformistas, demolidores, talvez sediciosos.

28 A atenção dispensada à historicidade dos conceitos históricos será desenvolvida em outras ocasiões por Buarque de Holanda, até mesmo como uma resistência à ambição de cientificização da história, em desacordo à qual, vale lembrar, ele se posiciona desde o início da conferência. A principal delas, porque texto exclusivamente dedicado a esta problemática, foi em I973, em meio à polêmica com Carlos Guilherme Mota, que, aliás, não se reduz à querela quase pessoal, e sim participa de um amplo debate sobre a escrita da história nos anos I970: "Ā velha superstição do fato puro substituiu-se a nova superstição do vocábulo puro, ou seja, perfeitamente unívoco, petrificado, e válido para todo o sempre” (HOLANDA, [I973] 20IIf, p. 42I-422). Já o ensaio sobre "O atual e o inatual na obra de Leopold von Ranke" vai, efetivamente, muito além de Ranke (I795-I886) e seu tempo. A frase de Ranke citada aqui por Buarque de Holanda significa, para além do aspecto puramente religioso, uma ênfase na particularidade dos acontecimentos históricos e uma recusa à teleologia das filosofias da história. Nesse sentido, Buarque de Holanda não deixou de mencionar as reflexões de Marc Bloch sobre Ranke, e até mesmo suas semelhanças: "Os dois caminhos assinalados por Bloch não diferem substancialmente dos caminhos descritos e separados por Leopold von Ranke: o da filosofia, que, no seu entender, é o reino das leis genéricas ou abstratas, e o da história, que, partindo da observação do único, deverá entretanto explicá-lo" (HOLANDA, I974, p. 442). Ou, ainda, a propósito de Lucien Febvre: “A separação entre a história e a filosofia não é uma exclusividade sua, e em nossos dias voltou a ser defendida com ênfase por um renovador dos estudos históricos na França” (HOLANDA, I974, p. 439). Publicado originalmente no número Ioo da Revista de História (I974), dossiê comemorativo organizado por Eurípedes Simões de Paula, o tema "Ranke" foi aberta e livremente escolhido por Buarque de Holanda, assim como o foi para todos os demais colaboradores, de Braudel a Silvio Zavala (I909-20I4) ou de Charles Boxer (I904-2000) a José Honório Rodrigues. No prefácio desse número, pelo reitor em exercício Orlando Paiva (I9I5-I989), este evocava o papel da revista para o desenvolvimento da "consciência que os historiadores têm de si mesmos na realidade histórica” (PAIVA, I974, p. viii). Pode-se supor que das mais fortes razões para a escolha deste tema por Buarque de Holanda tenha sido seu entusiasmo para com a recente descoberta da história dos conceitos. Em I973, Buarque de Holanda esteve na Alemanha. Foi quando muito provavelmente tomou notícia da publicação e adquiriu o primeiro volume, de I972, do "Léxico dos conceitos fundamentais da história na Alemanha", de Otto Brunner, Werner Conze e Reinhart Koselleck “A originalidade da concepção do léxico prende-se estreitamente a querer mostrar a transformação das noções, de maneira que a experiência nelas condensada permita esclarecer os aspectos teóricos. Não se pretende, contudo, oferecer definições abstratas e exteriores à história, que pudessem prescindir das mudanças de significação ao longo do tempo. [...] Nada destoa vivamente, nessa concepção, da tradição espiritual que Leopold von Ranke representou em grau eminente, renovada, embora, e enriquecida, para atender às mais recentes exigências do trabalho histórico” (HOLANDA, I974, p. 479-480). 
RAPHAEL GUILHERME DE CARVALHO é pósdoutorando no Instituto de Estudos Brasileiros da Universidade de São Paulo (IEB/USP), bolsista Fapesp, e doutor em História pela Universidade Federal do Paraná, com período de estágio no Institut d'Histoire du Temps Présent.

E-mail: raphaelguilherme83@gmail.com

\section{REFERÊNCIAS}

ASSIS, Arthur. A teoria da história como hermenêutica da historiografia: uma interpretação de Do Império à República, de Sérgio Buarque de Holanda. Revista Brasileira de História. São Paulo, v. 30, n. 59, 20I0, p. 9I-I20.

BLOCH, Marc. Apologie pour l'histoire ou métier d'historien. Paris: Armand Colin, I949. . Apologia da história ou o oficio de historiador. Trad. André Telles. Rio de Janeiro: Jorge Zahar, $200 I$. BOTELHO, André. Teoria e história na sociologia brasileira: a crítica de Maria Sylvia de Carvalho Franco. Lua Nova, n. 90, p. 331-366, 2013.

BRAUDEL, Fernand. Pour une histoire sérielle: Séville et l'Atlantique (I504-I650). Note critique. Annales. Économies, Sociétés, Civilisations. I8e année, n. 3, p. 541-553, I963.

. História e sociologia. Revista de História (USP), ano XVI, v. XXX, n. 6I, p. II-3I, I965a. Disponível em: <http://www.revistas.usp.br/revhistoria/article/view/I23302/II9648>. Acesso em: jun. 2018.

. História e ciências sociais: a longa duração. Revista de História (USP), ano XVI, v. XXX, n. 62, p. 26I-294, I965b. Disponível em: 〈http://www.revistas.usp.br/revhistoria/article/view/I23422/II9736〉. Acesso em: jun. 2018.

CALDEIRA, J. R. C. Sérgio Buarque de Holanda, mestre em Ciências Sociais. Notícia Bibliográfica e Histórica (PUCCAMP), v. 30, n. I70, p. 226-230, I998.

CALDEIRA, João Ricardo de Castro. IEB: origem e significados. Uma análise do Instituto de Estudos Brasileiros da Universidade de São Paulo. São Paulo: Imprensa Oficial do Estado, 2002.

CARVALHO, Marcus Vinicius Correa. Outros lados - Sérgio Buarque de Holanda: crítica literária, história e política (I920-I940). Tese (Doutorado em História). Departamento de História, Instituto de Filosofia e Ciências Humanas, Universidade Estadual de Campinas, 2003.

CARVALHO, Raphael Guilherme de. Sérgio Buarque de Holanda, do mesmo ao outro: escrita de si e memória (1969-I986). Tese (Doutorado em História). Setor de Ciências Humanas, Universidade Federal do Paraná, Curitiba, 20I7.

CARVALHO, T. C.; NEUMANN-WOOD, V.C. Referências bibliográficas de/sobre Sérgio Buarque de Holanda. In: EUGÊNIO, J. K.; MONTEIRO, P. M. (Org.). Sérgio Buarque de Holanda: perspectivas. Campinas, SP: Editora da Unicamp; Rio de Janeiro: EdUERJ, 2008, pp. 64I-668.

CHARLE, Christophe. Du bon usage des divergences entre histoire et sociologie. Actes de la recherche en sciences sociales, v. 20I-202, n. I, 20I4, p. IO6-III.

COELHO, Ruy Galvão de Andrada. Sociologia e história. Revista de História (USP), v. 38, n. 77, I969, p. 
II-25. Disponível em: 〈http://www.revistas.usp.br/revhistoria/article/view/I28504/I25350〉. Acesso em: jun. 2018.

DIAS, Maria Odila Leite da Silva. (I979). Sérgio Buarque de Holanda, historiador. In: (Org.) Sérgio

Buarque de Holanda. São Paulo: Ática, I985, p. 7-64. (Grandes Cientistas Sociais, 5I).

. Estilo e método na obra de Sérgio Buarque de Holanda. In: NOGUEIRA, Arlinda Rocha et al. (Org.).

Sérgio Buarque de Holanda: vida e obra. São Paulo: Secretaria de Estado da Cultura; Arquivo do Estado: Universidade de São Paulo: Instituto de Estudos Brasileiros, I988, p. 73-82.

. Entrevista. In: MORAES, José Geraldo Vinci; REGO, José Marcio (Org.). Conversas com historiadores brasileiros. São Paulo: Editora 34, 2002, p. I85-2Io.

DOSSE, François. História do estruturalismo. Volume I: O campo do signo (I945-I966). São Paulo: Ensaio; Campinas: Editora da Unicamp, I993.

. História do estruturalismo. Volume II: O canto do cisne: de I967 aos nossos dias. São Paulo: Ensaio; Campinas: Ed. Unicamp, I994.

DURKHEIM, Émile. O individualismo e os intelectuais. Edição bilíngue e crítica. Organização e edição de Marcia Consolim, Requel Weiss e Márcio de Oliveira. São Paulo: Edusp, 2016.

EUGÊNIO, João Kennedy. Ritmo espontâneo: organicismo em Raízes do Brasil, de Sérgio Buarque de Holanda. Teresina: EdUFPI, 20II.

FEBVRE, Lucien. FEBVRE, Lucien. Carnet de voyage au Brésil, I949, manuscrit, p. 82-83. [EHESS, Service d'archives, fonds Lucien Febvre].

. O homem no século XVI. Revista de História (USP), v. I, n. I, I950, p. 3-I7. Disponível em: <http:// www.revistas.usp.br/revhistoria/article/view/348I5/37553>. Acesso em: jun. 2018.

. Les lumières de Clio. In: BABEL, Antony et al. Le nouveau monde et l'Europe. Genève: Éditions La Baconnière, I955, pp. I6I-I75.

et al. Le Nouveau Monde et L'Europe. Rencontres Internationales de Genève, Tome IX. Neuchâtel: Les Éditions de la Baconnière, I954.

FRANÇOZO, Mariana. O Museu Paulista e a história da antropologia no Brasil entre I946 e I956. Revista de Antropologia (USP), v. 48, n. 2, 2005, p. 587-6I2.

HOLANDA, Maria Amélia Alvim Buarque de (I979). Apontamentos para a cronologia de Sérgio Buarque de Holanda. In: HOLANDA, Sérgio Buarque de. Raízes do Brasil. Edição comemorativa: 70 anos. Org. Ricardo Benzaquen de Araújo e Lilia Moritz Schwarcz. São Paulo: Cia. das Letras, 2006, p. 42I-446.

HOLANDA, Sérgio Buarque de. Les civilisations du miel. Annales. Économies, Sociétés, Civilisations. 5 année, n. I, p. 78-8I, I950.

. (I96-). Palestra proferida por SBH, discorrendo sobre o tema "História", a convite dos alunos do “Centro de Estudos Históricos Afonso de Taunay”. I7p. (orig. datil.c/anot.ms.) (anexo rascunho de 8p.) [Siarq - Fundo SBH: Série: Produção Intelectual: sub-série: originais/monografia: Pi I79].

. O atual e o inatual na obra de Leopold von Ranke. Revista de História (USP), ano XXV, v. L, n. Ioo, p. 43I-482, out./dez. I974. Disponível em: <http://www.revistas.usp.br/revhistoria/article/ view/I32639/I28724 >. Acesso em: jun. 2018.

. Tentativas de mitologia. São Paulo: Perspectiva, I979.

. (I948). Missão e profissão. In: __ _ O espírito e a letra: estudos de crítica literária II: I948-I959.

Organização de Antonio Arnoni Prado. São Paulo: Companhia das Letras, p. 35-40, I996a.

. (I974). O fardo do homem branco. In: . Livro dos prefácios. São Paulo: Companhia das Letras, p. I60, I996b.

. (I95I). O pensamento histórico no Brasil nos últimos 50 anos. In: EUGÊNIO, João Kennedy; MON- 
TEIRO, Pedro Meira (Org.). Sérgio Buarque de Holanda: perspectivas. Campinas: Editora da Unicamp; Rio de Janeiro: EdUERJ, p. 60I-6I5, 2008a.

. (I967). Elementos básicos da nacionalidade: o homem. In: EUGÊNIO, João Kennedy; MONTEIRO, Pedro Meira (Org.). Sérgio Buarque de Holanda: perspectivas. Campinas: Editora da Unicamp; Rio de Janeiro: EdUERJ, p. 6I7-637, 2008b.

. (I959). História brasileira num castelo medieval [Entrevista]. In: Encontros: Sérgio Buarque

de Holanda. Org. Renato Martins. Rio de Janeiro: Beco do Azougue, p. 64-67, $2009 a$. et al. (I977). Os velhos mestres [Entrevista]. In: . Encontros: Sérgio Buarque de Holanda. Org.

Renato Martins. Rio de Janeiro: Beco do Azougue, p. 96-I35, 2009b. . (I98I). Corpo e alma do Brasil [Entrevista]. In: . Encontros: Sérgio Buarque de Holanda. Org.

Renato Martins. Rio de Janeiro: Beco do Azougue, p. I74-I9I, 2009c.

. (I982). Todo historiador precisa ser um bom escritor. [Entrevista]. In: . Encontros: Sérgio

Buarque de Holanda. Org. Renato Martins. Rio de Janeiro: Beco do Azougue, p. I94-2II, 2009d. . (I948). Novos rumos da Sociologia. In: . Escritos coligidos: livro I, I920-I949. Org. Marcos Costa.

São Paulo: Editora Unesp; Fundação Perseu Abramo, p. 5I3-5I7, 20 IIa.

. (I950). Apologia da história. In: Escritos coligidos: livro II, I950-I979. Org. Marcos Costa. São

Paulo: Editora Unesp; Fundação Perseu Abramo, p. I8-2I, 20Irb.

. (I950). Para uma nova história. In: . Escritos coligidos: livro II, I950-I979. Org. Marcos Costa.

São Paulo: Editora Unesp; Fundação Perseu Abramo, p. 22-26, 20IIc. . (I95I). Uma biografia. In: Escritos coligidos: livro II, I950-I979. Org. Marcos Costa. São Paulo: Editora Unesp; Fundação Perseu Abramo, p. I56-I59, 20IId. . (I952). O senso do passado. In: . Escritos coligidos: livro II, I950-I979. Org. Marcos Costa. São

Paulo: Editora Unesp; Fundação Perseu Abramo, p. 2I6-2I9, 2011 .

. (I973). Sobre uma doença infantil da historiografia. In: . Escritos Coligidos: livro II, I950-I979.

Org. Marcos Costa. São Paulo: Editora Unesp; Fundação Perseu Abramo, p. 4I9-434, 20 IIf.

Raízes do Brasil. Edição crítica. Org. Lilia Moritz Schwarcz e Pedro Meira Monteiro. Texto e notas de Mauricio Aucuña e Marcelo Diego. São Paulo: Companhia das Letras, 2016.

JACKSON, Luiz Carlos. Gerações pioneiras na sociologia paulista (I940-I965). Tempo Social. Revista de Sociologia da USP, v. I9, p.II5-I30, 2007.

MOTA, Carlos Guilherme (Org.). Brasil em perspectiva. São Paulo: Difel, I968.

MOTA, Carlos Guilherme. Ideologia da cultura brasileira - I933-I974. São Paulo: Ática, I977. (Ensaios). . (I977). Os fazendeiros do ar. In: . História e contra-história: perfis e contrapontos. São Paulo: Globo, p. 3I-39, 2010.

NICODEMO, Thiago Lima. Urdidura do vivido: "Visão do Paraíso" e a obra de Sérgio Buarque de Holanda nos anos 1950. São Paulo: Edusp, 2008.

NORA, Pierre (Dir.). Essais d'ego-histoire. Paris: Gallimard, I987.

PAIVA, Orlando Marques de. Pequeno prefácio dedicado a uma grande obra. Revista de História (USP), ano XXV, v. L, n. Ioo, p. vii-viii, out./dez. I974.

PEIXOTO, Fernanda. Lévi-Strauss no Brasil: a formação do etnólogo. Mana: estudos de antropologia social, v. 4, n. I, p. 79-I07, I998.

REVEL, Jacques. Histoire et sciences sociales. Lectures d'un débat français autour de I900. Mil neuf cent. Revue d'histoire intellectuelle, 2007/I, n. 25, p. IOI-I26.

ROMÃO, Wagner de Melo. Sociologia e política acadêmica nos anos I960: a experiência do CEIT. Editora Humanitas, 2006. 
SIMIAND, François. Méthode historique et science sociale. Annales. Économies, Sociétés, Civilisations. I5e année, n. I, p. 83-II9, I960.

SPIRANDELLI, Claudinei Carlos. Trajetórias intelectuais: professoras do Curso de Ciências Sociais da FFCL-USP (I934-I969). Tese (Doutorado em Sociologia). Departamento de Sociologia, Faculdade de Filosofia, Letras e Ciências Humanas, Universidade de São Paulo, 2008. 